\title{
ASYMMETRIC OLIGOTHIOPHENES
}

\section{CHEMICAL EVOLUTION OF MULTIMODAL AMYLOID LIGANDS}

Leif B.G. Johansson

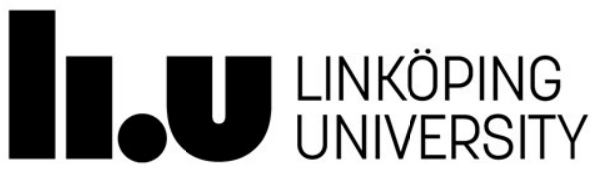

\author{
Division of Chemistry \\ Department of Physics, Chemistry and Biology \\ Linköping University \\ SE-581 83 Linköping, Sweden
}

Linköping 2015 
Cover: Depicts three different LCOs, used as surface capture agents, dissolved in $\mathrm{H}_{2} \mathrm{O}$, and their corresponding chemical structure, photo taken under UV-light at $366 \mathrm{~nm}$.

Courtesy of L and H Helmfors

During the course of research underlying this thesis, Leif BG Johansson was enrolled in Forum Scientium, a multidisciplinary doctoral program at Linköping University, Sweden

(C) Copyright 2015 Leif B.G. Johansson, unless otherwise noted

Published articles have been reprinted with permission from the publishers.

Paper 1 (C) 2011 The Royal Society of Chemistry

Paper 2 (C) 2015 Elsevier B.V.

Leif B.G. Johansson

Asymmetric oligothiophenes chemical evolution of multimodal amyloid ligands

ISBN: 978-91-7685-987-2

ISSN: 0345-7524

Linköping Studies in Science and Technology, Dissertation No. 1692

Printed by LiU-Tryck, Linköping, Sweden, 2015 
Hä löns int' förklar för den som int' begrip.

Ingemar Stenmark

mannen som inte bara har vunnit

Mästarnas Mästare (2011) och Let's Dance (2015) 
Det heter inte improvisera, det heter forska när man inte vet vad man gör!

\author{
Magnus och Brasse \\ i sketchen Kirurgerna \\ frain \\ Det är serverat (1978)
}




\section{ABSTRACT}

Luminescent conjugated polymers (LCPs) and luminescent conjugated oligothiophenes (LCOs) can be used as molecular probes to study diseases associated with protein aggregation. The conventionally used dyes to study and detect protein aggregates, denoted amyloid, have been Congo red (CR) and Thioflavin $\mathrm{T}$ (ThT). In contrast to these amyloid ligands, LCOs offer the possibility to detect aggregated proteinaceous species occurring at earlier stages of amyloid formation as well as to distinguish different morphotypes of protein aggregates. The interaction between the LCOs and the protein deposits can be studied by fluorescence spectroscopy and microscopy both in vitro and ex vivo.

In this thesis we report the development of multimodal asymmetric LCOs that can be utilized with two novel techniques, Surface Plasmon Resonance (SPR) and Positron Emission Tomography (PET), to study and visualize the interaction between LCO and amyloid fibrils in real time. With SPR, we have been able to determine binding affinities between LCO and amyloid, and with PET we have shown that radiolabelled LCOs might be used as a non-invasive method to study amyloid deposits in vivo. In addition, by alteration of the backbone (change of thiophene units), and of adding different side chain functionalities, we have shown that the properties of the amyloid ligands have a huge impact of the binding to different stages or forms of protein aggregates. By making asymmetrical LCOs, which can be attached to a surface, we also foresee a methodology that will offer the possibility to create a sensitive and selective detection method, and maybe lead to a lab-on-a-chip-application. 


\section{POPULÄRVETENSKAPLIG SAMMANFATTNING}

Tidigare arbete i Peter Nilssons forskargrupp har visat att luminiscenta konjugerade polymerer (LCPs) och luminiscenta konjugerade oligotiofener (LCOs) kan användas som molekylära prober för att studera sjukdomar associerade till protein aggregering. De konventionellt använda markörerna för att studera och detektera proteinaggregat, så kallad amyloid, är Kongorött (CR) och Thioflavin T (ThT). I kontrast till dessa konventionella markörer har Nilssons forskargrupp visat att LCOs, på grund av deras flexibla konjugerade struktur, och laddning kan upptäcka både tidigare stadier av proteinaggregat samt också skilja på olika typer av aggregat. När LCO interagerar med proteinaggregaten kan denna interaktion studeras med fluorescens mikroskopi både in vitro och ex vivo.

Arbetet $\mathrm{i}$ den här avhandlingen beskriver utvecklingen av amyloidligander från polymera till osymmetriska material samt två nya tekniker för att studera interaktionen mellan LCO och amyloida fibrer i realtid, Surface Plasmon Resonance (SPR) och Positron Emission Tomography (PET). Med SPR har vi kunnat bestämma bindingsaffiniteter mellan LCO och amyloida fibrer, och med PET har vi visat att radioinmärkta LCOs kan användas som en icke-invasiv metod för att studera amyloid in vivo. Under min forskarutbildning har jag syntetiserat och karaktäriserat både symmetriska och osymmetriska LCOs. Genom att förändra grundskelettet, d.v.s. förändra antalet tiofenenheter, samt att även ha olika funktionella grupper som sidokedjor, har vi visat att amyloidligandens egenskaper har stor inverkan på inbindningsförmågan till olika former av proteinaggregat. Vi har också visat att förmågan till interaktion mellan amyloida fibrer och LCO inte påverkas då oligotiofenerna kopplas till en yta, detta har medfört att interaktionen kunnat studeras och bestämmas. Att fästa molekylerna till en yta skapar nya möjligheter för att utveckla en känslig och selektiv detektionsmetod som i förlängningen skulle kunna leda till en lab-on-a-chip applikation. 


\section{PAPERS INCLUDED IN THE THESIS}

1. Klingstedt T, Åslund A, Simon RA, Johansson LBG, Mason JJ, Nyström S, Hammarström P, Nilsson KPR. Synthesis of a library of oligothiophenes and their utilization as fluorescent ligands for spectral assignment of protein aggregates. Org Biomol Chem. 2011, 9:8356-70.

2. Johansson LBG, Simon R, Bergström G, Eriksson M, Prokop S, Mandenius CF, Heppner FL, Asslund AK, Nilsson KPR. An azide functionalized oligothiophene ligand--a versatile tool for multimodal detection of disease associated protein aggregates. Biosens Bioelectron. 2015, 63, 204-211.

3. Nordeman P, Johansson LBG, Bäck M, Estrada S, Hall H, Sjölander D, Westermark GT, Westermark P, Nilsson L, Hammarström P, Nilsson KPR, Antoni G. 11C and 18F Radiolabeling of Tetra- and Pentathiophenes as PET-ligands for Amyloid Protein Aggregates.

Under revision 2015.

4. Johansson LBG, Bäck M, Lantz L, Eriksson M, Nygren P, Nilsson KPR. A variety of thiophene based ligands for detection of protein aggregates by surface plasmon resonance.

Manuscript 2015. 


\section{CONTRIBUTION TO INCLUDED PAPERS}

Paper I: Leif Johansson (LBGJ) performed synthesis of some of the molecules and participated in the characterization of the molecules.

Paper II: LBGJ planned and performed all experiments, wrote and edited the manuscript together with KPR Nilsson.

Paper III: LBGJ participated in the planning of the project, performed synthesis and characterization of the molecules, and edited the final manuscript. LBGJ participated in the writing of the manuscript.

Paper IV: LBGJ planned and performed the experiments, and some synthesis and characterization of the molecules. LBGJ participated in the writing of the manuscript. 


\section{CONFERENCE CONTRIBUTIONS}

Leif B. G. Johansson, K. Peter R. Nilsson. Synthesis and functionalization of asymmetrical luminescent conjugated oligothiophenes.

2nd European Amyloid Symposium, 2010, Sonderbjerg Denmark.

Leif B.G. Johansson, K. Peter R. Nilsson. Synthesis of a Functionalized Multifunctional Amyloid Ligand. XIVth Conference on Heterocycles in Bio-organic Chemistry, 2011, Brno, Czech Republic.

Sofie Nyström, Erin Nelson, Nina Reitan, Pal Ellingsen, Ann-Christin Brorsson, Jeffrey Mason, Leif Johansson, Chanan Sluzny, Susann Handrick, Stefan Prokop, Bettina Wegenast-Braun, Simone Hornemann, Katarina Kågedal, Mikael Lindgren, Frank Heppner, Mathias Jucker, Adriano Aguzzi, Peter Nilsson and Per Hammarström. Monitoring amyloid Formation and Maturation in vitro and in vivo Using LCO Fluorescence. Prion 2012, 2012, Amsterdam, Netherlands.

Leif B.G. Johansson, K. Peter R. Nilsson. Synthesis Of Molecular Probes For Detection Of Protein Aggregates Using PET And SPR.

International Conference on Science and Technology of Synthetic Metals, ICSM. 2012, Atlanta, USA.

Leif B. G. Johansson, Rozalyn A. Simon, Gunnar Bergström, K. Peter R. Nilsson. Characterisation of amyloidligands using Surface Plasmon Resonance.

Biosensors 2014, 2014, Melbourne, Australia. 


\section{PAPERS NOT INCLUDED IN THE THESIS}

Nyström S, Psonka-Antonczyk KM, Ellingsen PG, Johansson L, Reitan N, Handrick S, Prokop S, Heppner FL, Wegenast.Braun BM, Jucker M, Lindgren M, Torger Stokke B, Hammarström P and Nilsson KPR

Evidence for Age-Dependent in Vivo Conformational Rearrangement within A beta Amyloid Deposits

ACS Chemical Biology, 2013, 8 (6), 1128-1133. 


\section{THESIS COMMITTEE}

SUPERVISOR

Peter Nilsson, Professor

Division of Organic Chemistry

Department of Physics, Chemistry and Biology

Linköping University, Sweden

CO-SUPERVISOR

Peter Konradsson, Professor

Division of Organic Chemistry

Department of Physics, Chemistry and Biology

Linköping University, Sweden

\section{OPPONENT}

Mikael Elofsson, Professor

Department of Chemistry

Umeå University, Sweden

COMMITTEE BOARD

Joakim Bergström, Senior Lecturer

Department of Public Health and Caring Sciences

Uppsala University, Sweden

Karin Enander, Associate Professor

Division of Molecular Physics

Department of Physics, Chemistry and Biology

Linköping University, Sweden

Kristina Luthman, Professor

Department of Chemistry and Molecular Biology

Göteborg University, Sweden 


\section{ABBREVIATIONS}

$A \beta \quad$ amyloid $\beta$

BBB blood-brain-barrier

C-C carbon-carbon bond

CuAAC copper-catalyzed azide-alkyne cycloaddition

CR congo red

DBCO dibenzocyclooctyne

DSC differential scanning calorimetry

EDC $\quad N$-(3-Dimethylaminopropyl)- $N$ '-ethylcarbodiimide

GRIM Grignard metathesis method

$\mathrm{HH}$ head-head

HT head-tail

ITC isothermal titration calorimetry

$\mathrm{K}_{\mathrm{a}} \quad$ association constant

$\mathrm{K}_{\mathrm{d}} \quad$ dissociation constant

LC/MS liquid chromatography/mass spectrometry

LCO luminescent conjugated oligothiophene

LCP luminescent conjugated polythiophene

NBS N-bromosuccinimide

NHC N-heterocyclic carbene

NHS N-hydroxysuccinimide

NIS N-iodosuccinimide

NFT neurofibrillary tangles

MDS meso scale discovery protein assay

PBS phosphate buffered saline

Pd palladium

PEPPSI pyridine enhanced precatalyst preparation stabilisation

PiB Pittsburgh compound B

PET positron emission tomography

RFU relative fluorescence unit

RU response or resonance unit

SPR surface plasmon resonance

TEG tetra ethylene glycol

ThT thioflavin $\mathrm{T}$

TLC thin layer chromatography

TT tail-tail 


\section{CHEMICAL STRUCTURES AND NOMENCLATURE}
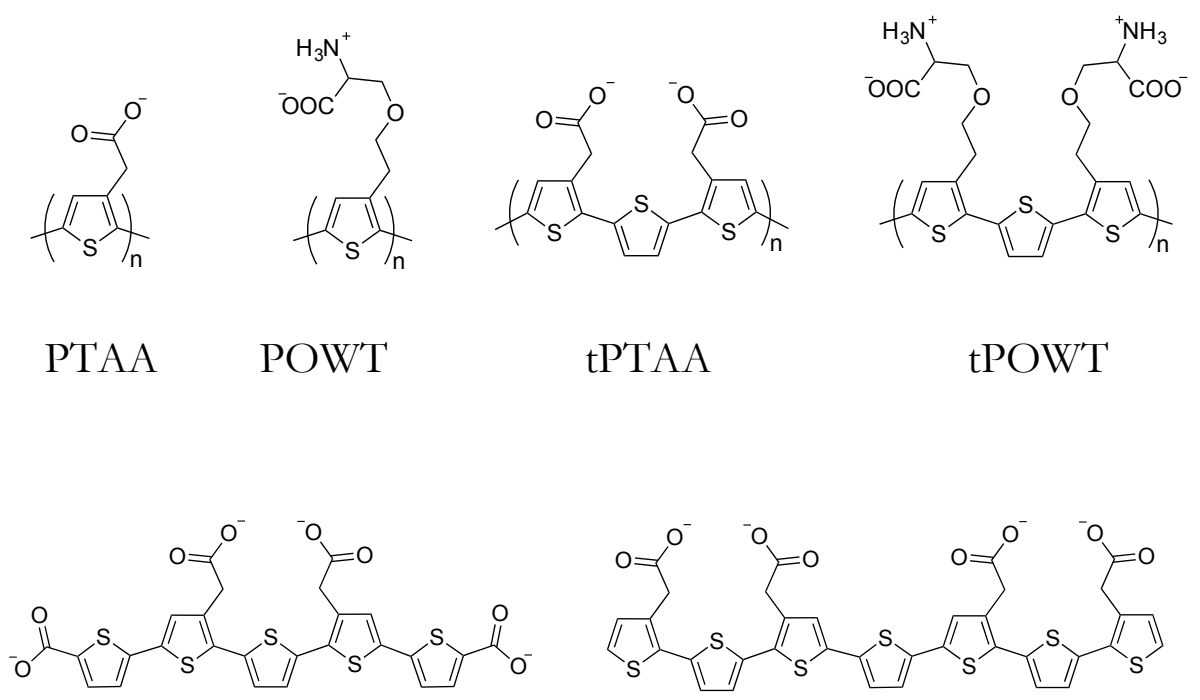

p-FTAA

h-HTAA
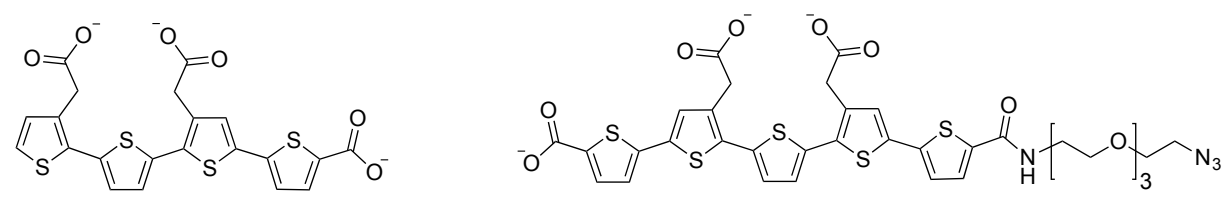

q-FTAA

p-FTAA-Azide

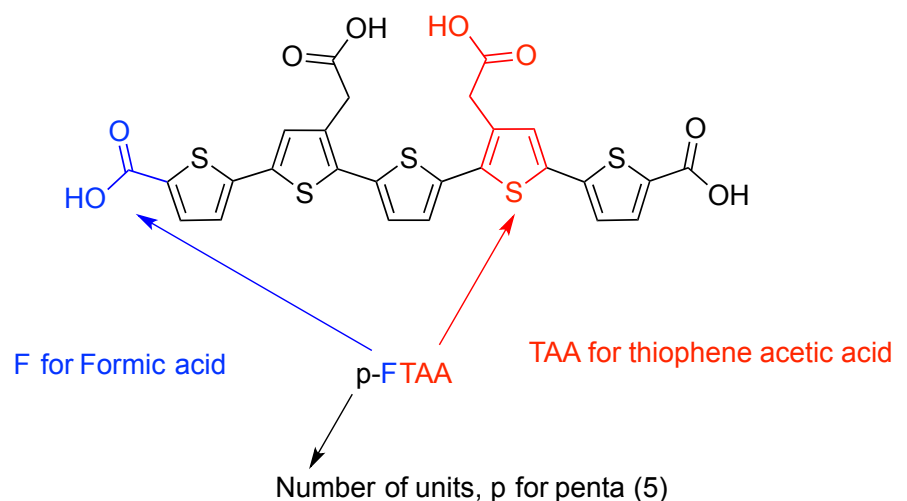




\section{CONTENTS}

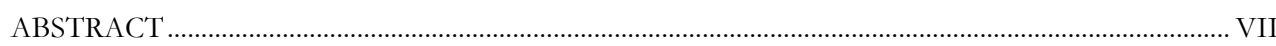

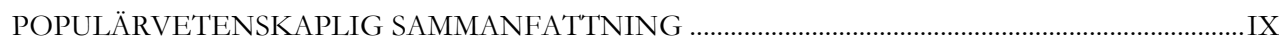

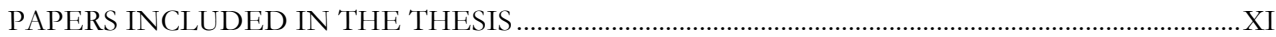

CONTRIBUTION TO INCLUDED PAPERS................................................................................ XII

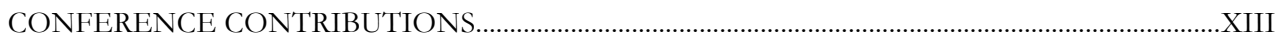

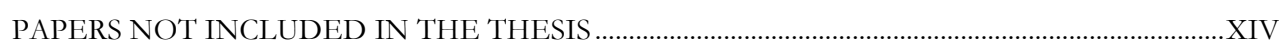

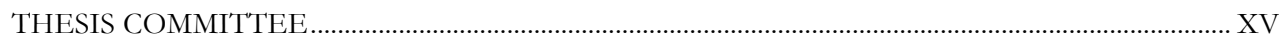

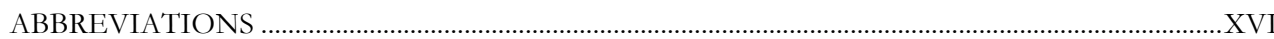

CHEMICAL STRUCTURES AND NOMENCLATURE................................................................... XVII

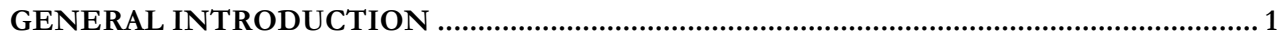

INTRODUCTION TO CONJUGATED POLY- AND OLIGOTHIOPHENES ........................ 3

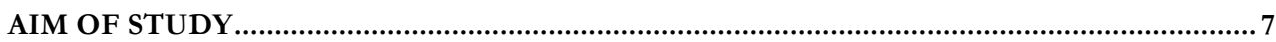

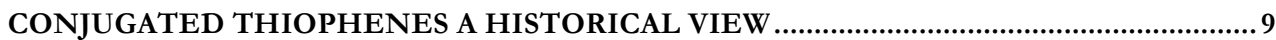

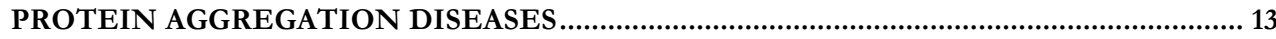

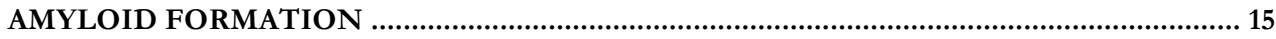

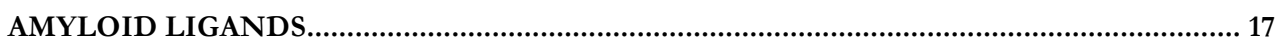

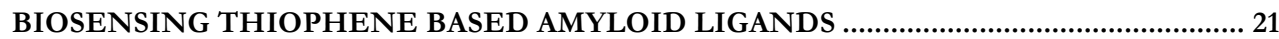

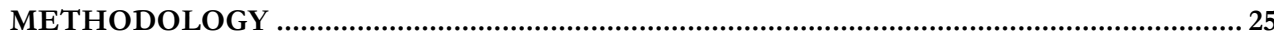

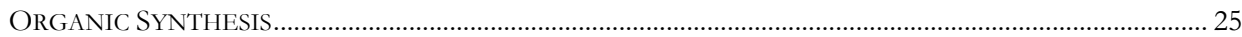

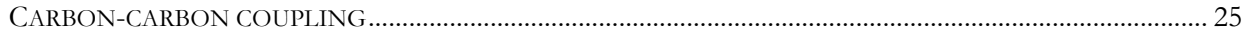

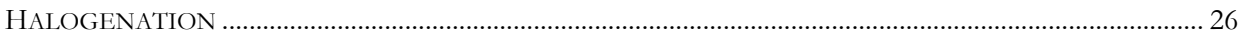

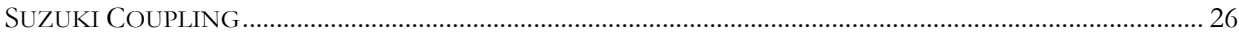

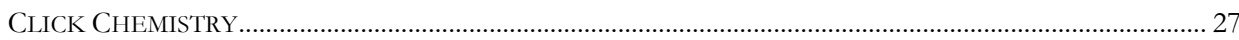

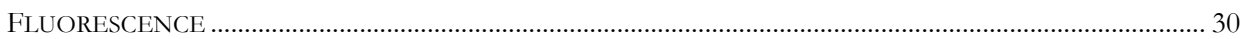

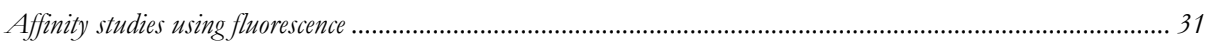

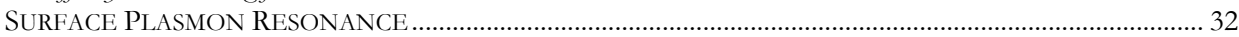

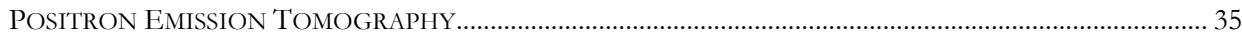

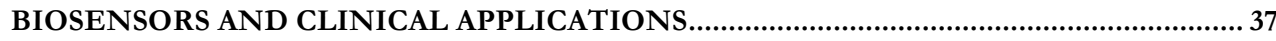

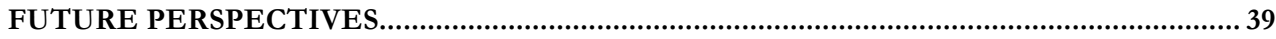

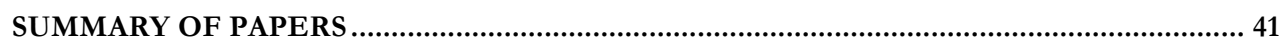

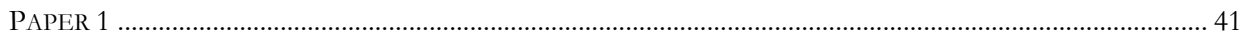

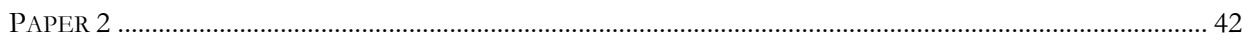

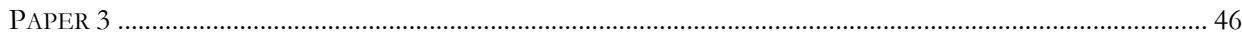

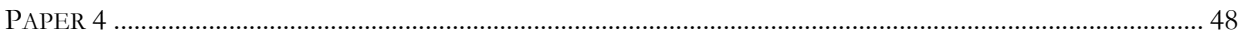

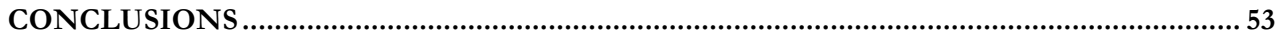

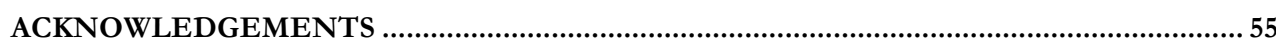

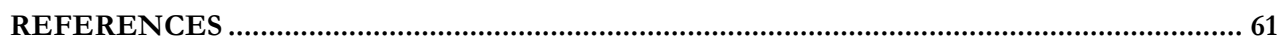




\section{GENERAL INTRODUCTION}

Over the years molecules have been used as an important tool for diagnosis and treatment of diseases. Advancement in bio- and organic chemistry has made it possible to visualize and study disease progression in tissue and cells down to the molecular level. These new techniques have the potential to lead to early detection of disease and, consequently, a rapid initiation of treatment. In this thesis, a class of compounds denoted conjugated poly-and oligothiophenes, that can be used to study neurodegenerative diseases has been chemically modified with the aim of achieving molecules that can be utilized to study protein aggregation and the aggregates role in neurodegenerative diseases in a more refined manner, as well as for clinical diagnostics of these diseases. 


\section{INTRODUCTION TO CONJUGATED POLY- AND OLIGOTHIOPHENES}

If you are going to write about "conjugated poly-and oligothiophenes" you first need to have the terminology straightened out.

So, first thing first, thiophene is an organic aromatic heterocyclic compound, consisting of four carbon atoms, one sulfur atom in a five membered ring. The sulfur atom is relatively unreactive, but the neighboring carbons at 2-and 5positions, ( $\alpha$-positions), are highly reactive toward electrophiles. Thiophenes are widely used as building blocks in both pharma-and agrochemical industries [1].

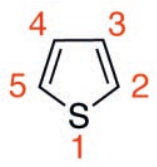

Figure 1. Chemical structure of thiophene, position 2 and 5 for now on referred to as $\alpha$-positions, 3 and 4 as $\beta$-positions.

By linking thiophenes at their $\alpha$-positions, a material called polythiophene can be formed. Polymer, from greek poly-many and mer-parts is a large molecule composed of many repeated subunits, (monomers). A polymer could either be a homopolymer, formed by identical monomers or a hetero-polymer, by different monomers, it could also be regioirregular, if the monomer is asymmetrical, or regioregular if a symmetrical monomer is polymerized. Oligo, means "a few" and in contrast to a polymer the subunits in an oligomer are limited to a specific number [2]. When a material is poly-or oligo is debated, but instead of arguing about how many monomers they should consist of, another definition relies on whether the material will change its properties if one or more units are removed. If so, the material should be characterized as an oligomer[3].

Another difference between poly-and-oligomers is that polymers often consists of polymer chains of different lengths, the mixture have a Gaussian distribution of different chains, a phenomenon known as polydispersity. An oligomer on the other hand, is often well defined in chain length, and thereby called monodispersed. The advantage with an oligomeric material could be that you are certain that there is just one chain length in your material. This could avoid inconsistences in material behavior.

In chemistry, a conjugated system is defined as, a molecule with alternating single and multiple bonds, with connected p-orbitals and delocalized electrons. This will lead to increased stability and will also give the molecule ability to absorb and emit 
light or transport electrical charges and conjugated systems are widely used in applications such as such as solar cells[4,5], LED-displays[6,7] and biosensors[8,9]. A conjugated system may be linear, cyclic or mixed. In a conjugated system there is an overlap of p-orbitals, bridging the single bonds. The pi-electrons in the system do not belong to a single bond or atom; they are rather shared all over the system. The largest conjugated system can be found in carbon nanotubes, graphene and conductive polymers.

Due to the rotational freedom around the single bonds, the conformation of the thiophene backbone can change and thereby change the effective conjugation length in the system. These conformation changes, due to twisting, flattening or aggregation of the probes itself will affect the effective conjugation length and thereby affect the photo physical properties. As exemplified in figure 2, certain conformational changes of the thiophene backbone will alter the wave lengths of the absorbed and emitted light observed from the molecule[10]. A planar conformation as in figure 2a) will increase the conjugation length i.e. the electrons have the ability to move over all the thiophene backbone, and give a more redshifted emission spectra, as in b) when the backbone is more twisted the conjugation length will decrease and the emission will shift towards shorter bluer wave length with higher energy. Also the effect of probe-probe interaction or aggregation c) will change the emitted light towards more red-shifted spectra, and also a decrease in intensity of the emitted light could be seen.

It is this unique photo-physical behavior that can be utilized to study, when a probe interacts with a biomolecule, as in this thesis topic LCO-amyloid interaction. 


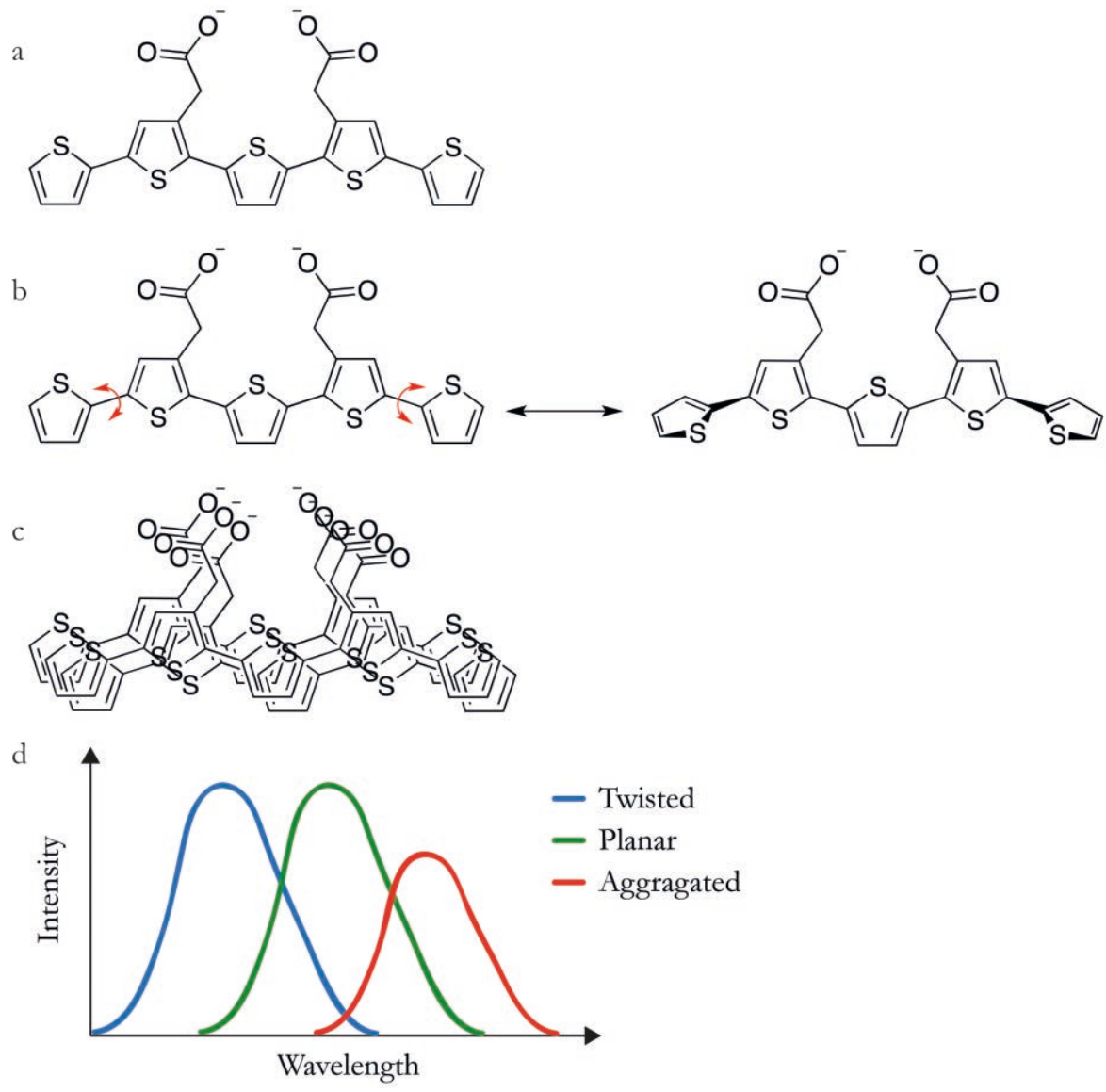

Figure 2. a) The planar structure of an LCO. b) shows the rotational freedom along the flexible backbone, here exemplified of the outer thiophene units' rotation. c) shows the aggregated form of an LCO and d) schematic presentation of the emission spectral differences.

Over the years, our group has developed tools for studying, diagnosing as well as treating protein aggregate diseases.

The tools used are thiophene based molecules denoted luminescent conjugated polythiophenes (LCP) and luminescent conjugated oligothiophenes (LCO). The historical development has been from polymeric material via well-defined oligomers to this thesis focus asymmetrical compounds. The synthetic pathways between polymers and oligomers differ: a polymer is synthesized in a continuous flow of adding monomer units until the chain is stopped when there are no more monomers to react or the system has reached its equilibrium. Oligomers on the 
other hand are built step by step, often with more or less complicated purification steps in between. The synthesis will be explained and discussed in more detail in the following section. 


\section{AIM OF STUDY}

The aim of this study was to chemically modify symmetric luminescent oligothiophenes to asymmetric, and to investigate if these compounds will provide the possibility to be utilized in complementary techniques to fluorescence spectroscopy, such as SPR and PET for detecting the LCO-amyloid interaction.
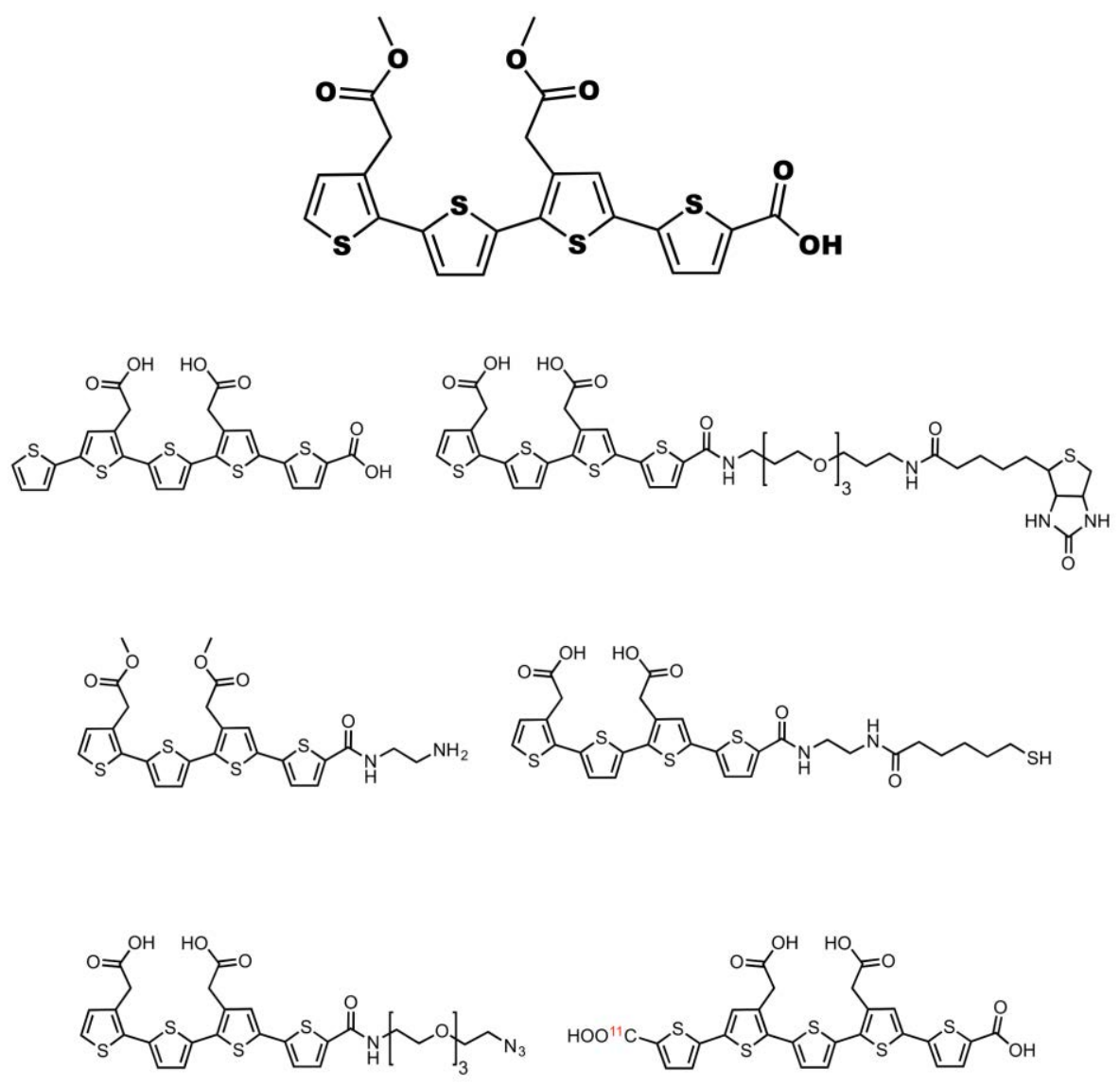

Figure 3. Scheme of possible compounds available from asymmetric LCO synthesis. 


\section{CONJUGATED THIOPHENES A HISTORICAL VIEW}

Chemical synthesis of unsubstituted polythiophenes was first described in the 1980s of Yamamoto and Lin[11,12]. They both used 2,5-dibromothiophene in a metal-catalyzed polycondensation polymerization. The polymerization reaction is a variant of the Kumada cross coupling, using nickel or palladium in a Grignard coupling with an organic halide[13]. In 1984 Sugimoto et al. published a synthetic route using iron(III)chloride $\left(\mathrm{FeCl}_{3}\right)$ as a Lewis acid and polymerization catalysts in anhydrous chloroform $\left(\mathrm{CHCl}_{3}\right)[14]$.

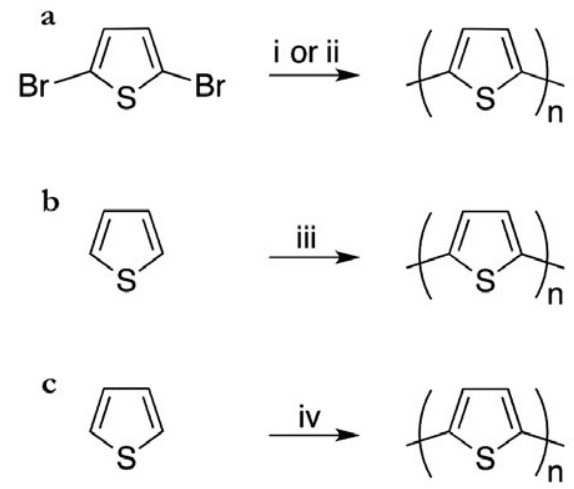

Figure 4. Different type of early polymerization reactions. i) $\mathrm{Mg} / \mathrm{THF}$, $\mathrm{Me}(\text { acetylacetonate })_{\mathrm{n}}(\mathrm{Me}=\mathrm{Ni}, \mathrm{Pd}, \mathrm{Fe}, \mathrm{Co})$; ii) $\mathrm{Mg} / \mathrm{THF}, \mathrm{Ni}$ (bipy) $\mathrm{Cl}_{2}$ iii) $\mathrm{FeCl}_{3}$, $\mathrm{CHCl}_{3}$. (bipy=2,2'-bipyridine).

Since all these groups used a symmetric monomer the resulting polythiophenes were regioregular. As mentioned earlier one drawback with polymerization of asymmetric monomers is the regioirregularity of the obtained material. When polymerizing an asymmetric molecule, there are three possible orientations between the two thiophene units when coupling at the 2-and 5-positions: head-totail coupling (HT) 2-5', head-to-head coupling $(\mathrm{HH})$ 2-2' and tail-to-tail coupling (TT) 5-5'. The favorable coupling in a polymer chain is HT-coupling. HT or regioregular polymers are considered highly conjugated and give access to a low energy conformation. In comparison, a polymer with unfavorable $\mathrm{HH}$ coupling could loose its conjugation due to steric hindrance in the polymer backbone[15]. 


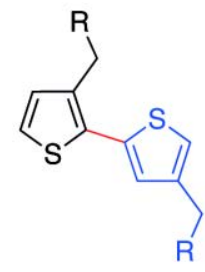

2-5

Head-Tail

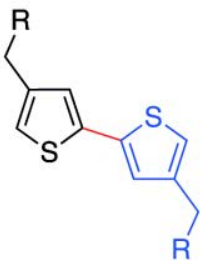

5-5

Tail-Tail

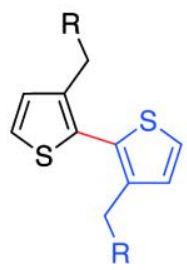

2-2

Figure 5. Possible regio-orientations of a $\beta$-substituted monomer.

In 1992 McCullogh and Lowe reported the first synthesis of a $\beta$-substituted regioregular HT polymer. By using the Kumada cross coupling and a monobrominated starting material, they created a Grignard reagent which then was polymerized yielding over $90 \%$ of HT-coupled polymer[16].

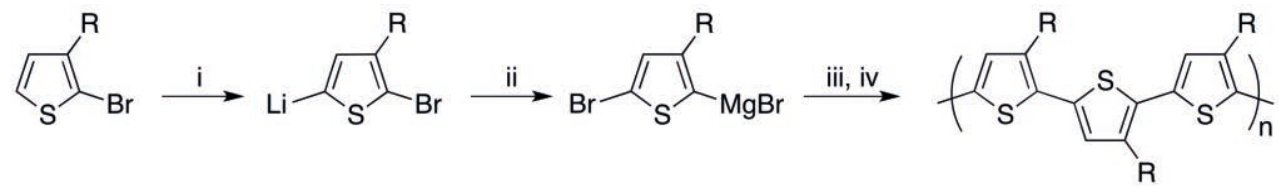

Figure 6. Selective polymerization method as reported from McCullogh and Lowe.

i) LDA, THF, $-40{ }^{\circ} \mathrm{C}$; ii) $\mathrm{MgBr}_{2} \cdot \mathrm{OEt}_{2},-60{ }^{\circ} \mathrm{C}$; iii) $-10^{\circ} \mathrm{C}, \mathrm{Ni}(\mathrm{dppp}) \mathrm{Cl}_{2},-5-25{ }^{\circ} \mathrm{C}$;

(LDA=lithium diiospropylamide, $\mathrm{dppp}=1,3$-bis(diphenylphosphino)propane).

Having a successful strategy for synthesizing regioregular polymers, it became of interest to incorporate different side chain functionalities at the $\beta$-position. McCullough et al. developed two different strategies to accomplish side chain functionalization, either the monomer is functionalized first and then polymerized or the monomer is polymerized and then functionalized. The polymerization reaction used in both cases was Grignard Metathesis (GRIM) [17,18]. This is a method that can be performed at room temperature and is easily up-scaled. It uses a di-brominated $\beta$-substituted monomer that is treated with an alkylated Grignard reagent, resulting in a magnesium-bromine exchange reaction. The intermediate is then polymerized. 


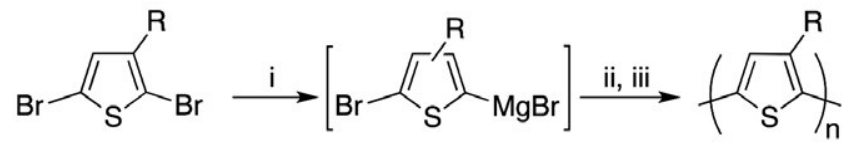

Figure 7. Regioregular HT-coupled poly(3-alkylthiophenes) i)R'MgX, THF, reflux; ii) $\mathrm{NI}(\mathrm{dppp}) \mathrm{Cl}_{2}$; iii) $\mathrm{MeOH}$.

The main application of these $\beta$-side chain functionalized polymers was still as building blocks in electrical devices, such as transistors and nanoscale materials.

To use conjugated polythiophenes as biosensors requires that the molecules are bio compatible and water- soluble. In this regard, ionic substituents along the repetitive thiophene backbone have been introduced[19,20]. Many groups have used the $\mathrm{FeCl}_{3}$ route discussed above to generate conjugated polymers in many different biosensing applications, e.g. virus detection[21],DNA hybridization[22,23] and protein misfolding studies[24,25]. One of the first groups to use conjugated polymers as conformational dependent bioimaging-agents was Charych et al. Their application was to covalently bind a polymer to influenza virus and use the conformational color change of the polymer as detection signal[26]. Later LeClerc et al. reported a method to detect specific DNA sequences using a positively charged conjugated polymer[23]. In 2003 Nilsson and co-workers used LCOs to study conformational changes of synthetic peptides[27] When they mixed the polydispersed zwitterionic POWT with a cationic peptide (JR2K), they saw a blue shift and an increase in emission. When POWT was mixed with anionic (JR2E) the emission decreased and was shifted to the red. These findings was explained by conformational changes of the polymer backbone, and that the LCP could detect different forms of a peptide, led to ideas to test these molecules as amyloid ligands and to study protein aggregation, a common pathological hallmark for many devastating diseases. 


\section{PROTEIN AGGREGATION DISEASES}

To date, around 30 different proteins that forms disease associated protein aggregates, so called amyloid, have been identified[28] The common protein aggregation diseases e.g. bovine spongiform encephalopathies (BSE, or mad cow disease), sheep scrapie (SC), Creutzfeldt Jacob disease (CJD), Parkinson's, Huntington's, Alzheimer's diseases, and systemic amyloidoses are all associated with amyloid deposits in a certain organ. For example, in the aging population today, the most common form of dementia is Alzheimer's disease (AD). AD affects cognitive brain functions, like social skills, learning and memory. The German psychiatrist Alois Alzheimer was the first to describe AD over hundred years ago[29]. AD causes great suffering and affects the everyday life for both patients and their families and since the population today grows older it also generates large economical challenges for both society and health-care system[30]. The classical pathological hallmarks of $\mathrm{AD}$ are accumulation of extracellular amyloid- $\beta$ (A $\beta$ ) protein and intracellular neurofibrillary tangles (NFTs), see figure 8 , together with shrinking of brain volume. Thus, it is of great interest to develop novel tools for these pathological hallmarks, as such tools might aid in early and rapid diagnostic of these diseases, as well as be utilized for accurate evaluation of the potential effect of novel therapeutics towards these diseases. Today, an efficient therapeutic approach towards preventing the suggested pathological process of $\mathrm{AD}$ is lacking.

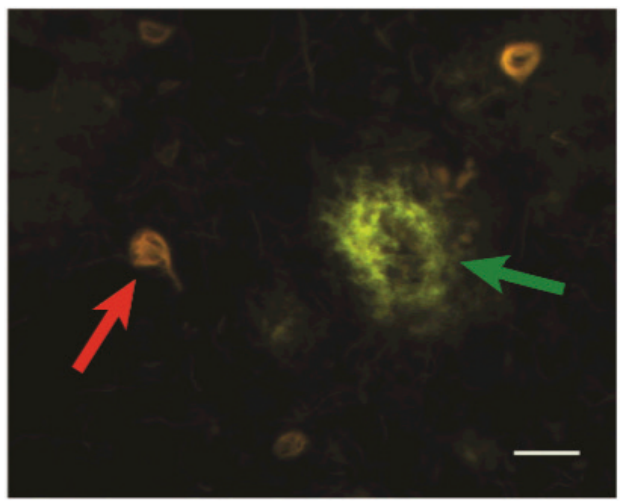

Figure 8. Fluorescence image of human AD brain tissue stained with the LCO hFTAA. The image visualize A $\beta$ plaques (green arrow) and NFTs (red arrow). Scale bars represent $20 \mu \mathrm{m}$. Reprinted with permission from the Royal Society of Chemistry[31]. 


\section{AMYLOID FORMATION}

One definition of amyloid is that they are formed from misfolded, or partially misfolded proteins, which then forms protein aggregates. Another definition of amyloid fibril protein is that the protein must occur in body tissue deposits and have affinity for Congo red. The aggregation pathway is often described in three phases; lag- growth and stationary- (or plateau)-phases [32,33]. The fibrillar structure is a $\beta$-sheet rich structure and the fibrils are organized in $\beta$-strands, orientated perpendicular to the fibril axis and connected through a hydrogenbonding network. The size of this elongated nanostructure is typically $2-15 \mathrm{~nm}$ in diameter and a length of $0.5-10 \mu \mathrm{m}$, and assemblies of these nanostructures is called amyloid plaque, when occurring in e.g. brain tissue.

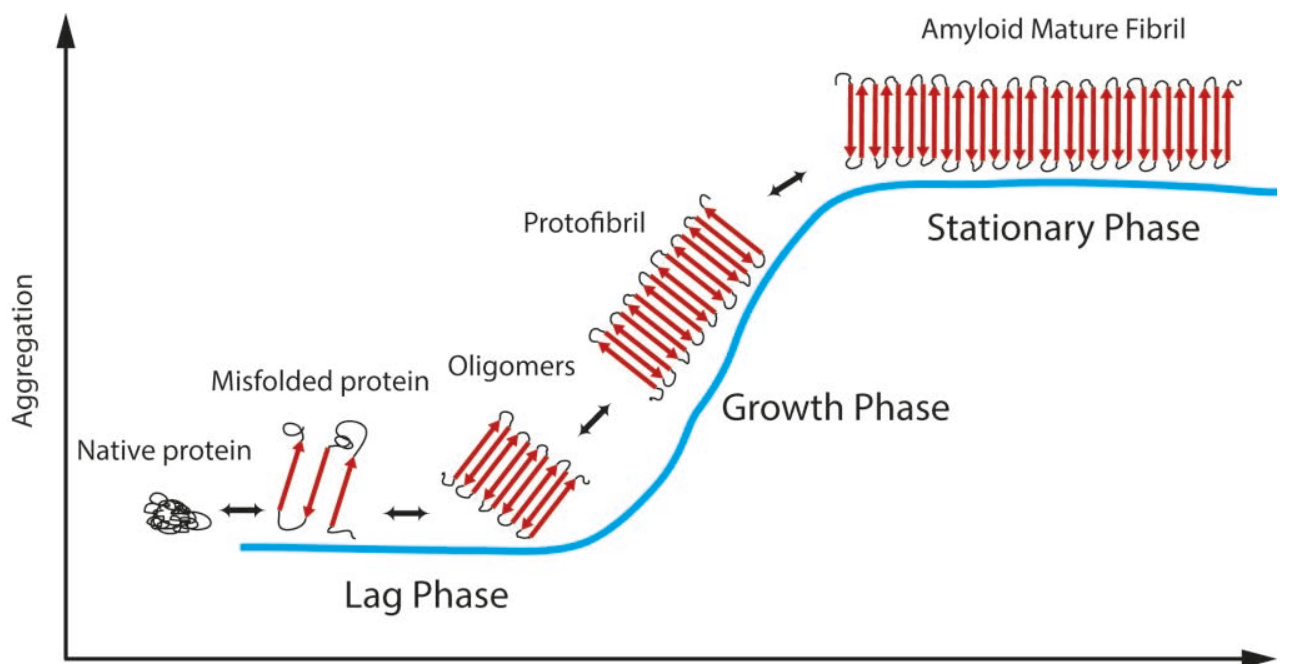

Time

Figure 9. General scheme of in vitro fibril formation described over time.

The amyloid formation or aggregation pathway is often described as a nucleationdependent polymerization mechanism where the native soluble protein forms a misfolded state with $\beta$-sheets, due to thermodynamics this is the rate-limiting step, during the late lag phase oligomers starts to form which under the growth phase will go into protofibrils to finally in the stationary phase form insoluble mature fibrils[34,35]. During the formation there is equilibrium between all the different species. One interesting thing is that seeding can shorten the rate-limiting step in the lag phase, which means that pre-fibrillar state of the protein is added and can work as a template for further aggregation. [36,37]. 


\section{AMYLOID LIGANDS}

To understand the mechanism of protein misfolding diseases and to diagnose these disorders it is important to be able to stain and image protein aggregates. This has earlier been done by immunohistochemistry, using antibodies, but since antibodies have shown limitations, small organic hydrophobic probes have been developed and used as specific amyloid ligands. A specific ligand is a ligand that is able to distinguish misfolded and native proteins, and maybe even distinguish different protein aggregates. The disadvantage using antibodies could be that most antibodies bind to a special site of amino acids and cannot separate native and misfolded proteins, meaning if it is possible for the antibody to reach the binding site in the misfolded state it will bind, and then it is not possible to separate the two states. The most commonly used dyes that only bind to aggregated proteins are Congo red, Thioflavin $\mathrm{T}$ and derivatives thereof. In our group we have developed luminescent conjugated polythiophenes and oligothiophenes, with properties to image and separate protein aggregates.

Congo red, the golden standard for amyloid detection, is an aromatic symmetrical azo compound with sulfonate groups. Studies have shown that the most important functionalities may be the two negatively charged sulfonic acid groups and the spacing between them[38,39]. The binding of CR to amyloid is debated, but one model is that the dye orients perpendicular to the fibril axis and CR binds as monomer, oligomer or micelle[40,41] or is intercalated between $\beta$-sheets[42]. Others suggest hydrophobic, aromatic, ionic or hydrogen bonding interactions between dye and fibril structure. And also different side chain interactions from e.g. lysine[38], arginine[43] and histidine[44] have been suggested to help the binding. When Klunk et al. synthesized an analogue to CR, Chrysamine G, with two carboxylic groups replacing the sulfonate groups, they saw that this molecule had the same affinity for protein aggregates as CR [45] and it has been shown that negatively charged analogues of $\mathrm{CR}$ can pass the $\mathrm{BBB}$ and show uptake in the brain[46].

Thioflavin $\mathrm{T}(\mathrm{ThT})$ is another small organic dye used for in vitro characterization of amyloid formation and staining of amyloid deposits[47,48].

In contrast to $\mathrm{CR}$ and some analogues thereof, ThT is a positively charged molecule, with a benzothiazolium unit, which make ThT unfavourable for brain uptake. Although ThT has a positive charge several amyloid lignads have been developed using this scaffold. For instance, Klunk et al. developed neutral ThT derivatives, where the benzothiazolium unit was replaced by benzothiazole for PET imaging $[49,50]$. These molecules all neutral showed higher binding affinities 
towards protein aggregates than charged ThT. One of these derivatives Pittsburgh Compound $\mathrm{B}(\mathrm{PiB})$ has been used in PET studies with promising results[51].
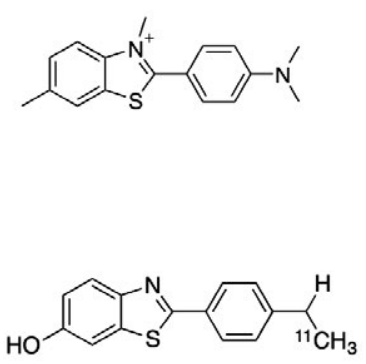
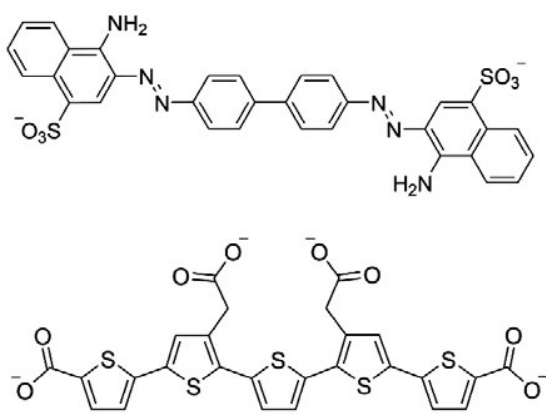

Figure 10. Chemical structures of different amyloid ligands, ThT (top left), CR (top right), PiB (bottom left) and pFTAA (bottom right).

The binding mechanism of amyloid to amyloid ligand is yet not fully known, but by using solid-state NMR, the binding between amyloid ligands and amyloid fibrils of HET-s(218-289) protein has been studied [52,53]. Schütz et al. has studied the interaction CR-HET-s and Herrmann et al. has studied interaction between LCOs and HET-s. These two studies showed that the dyes bind highly site-specifically by interacting with residues in the $\beta$-sheet structure .The 3D-structure of the fibril formed from HET-s and how the two dyes interacts, with specific amino acids is shown in figure 11.

In the modulation of the p-FTAA-HET-s interaction (left) the two residues most important for binding are Lys229 (dark blue) and Glu265 (light blue). In the model the four carboxylic groups of p-FTAA, interacts with the amine of the four lysine residues. When looking at the CR-HET-s interaction (right), it shows that the two sulfonic acids in CR interact with two Lys229 in a similar matter as p-FTAA. 

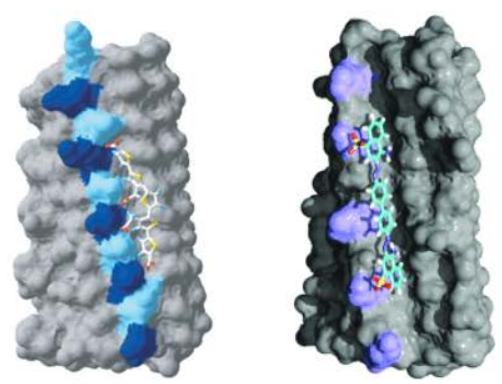

Figure 11. The picture shows (left) p-FTAA binding to four lysine residues in the fibril structure of HET-s fibrils and (right) CR binding to two lysine residues in HET-s fibrils. Reprinted with permission from American Association for the Advancement of Science[53] and John Wiley \& Sons, Inc. [52]

If there are so many different amyloid ligands today, why do we need LCOs? As we have seen in Paper 1, small changes in length of the backbone and changes of $\alpha$-position functionalities have large impact of the LCOs properties as amyloid ligands. The chemical alterations give possibilities to spectrally distinguish $A \beta$ plaques and NFTs and also to detect non-thioflavinophilic A $\beta$ species and by further optimization of the LCOs, it may be possible to detect other kind of proteins, earlier forms of $\mathrm{A} \beta$ species, develop new techniques to investigate amyloid fibrils-LCO interaction, (hence Paper 2 and Paper 4), with the final goal of achieving improved diagnostic, Paper 3, and therapeutic tools.

So in that regard, it is easy to justify the development of new LCOs. 


\section{BIOSENSING THIOPHENE BASED AMYLOID LIGANDS}

The development of biosensing polythiophenes as amyloid ligands used in our group starts with polydisperse monomer based regioirregular polythiophenes, exemplified here by PTAA[20], it continues with trimer based regioregular polythiophenes (tPTAA)[24], followed by well-defined LCOs, (p-FTAA)[54], to finally end up in this thesis focus asymmetrical LCOs, (q-FTAA)[31].

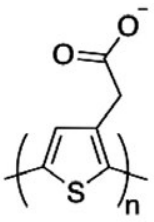

1

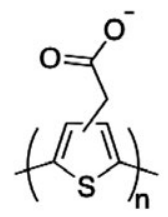

2

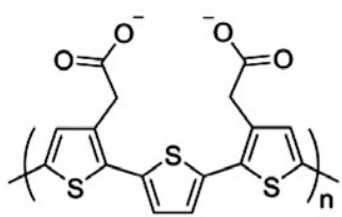

3

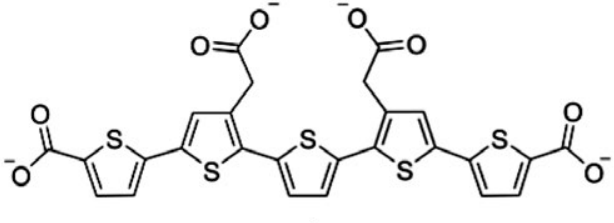

4

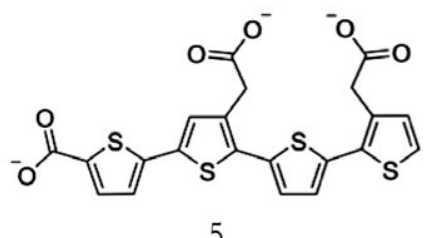

5

Figure 12. Structures of regioirregular PTAA (1) (commonly written structure), (2) (more accurately written), regioregular tPTAA (3), well-defined p-FTAA (4), welldefined asymmetrical q-FTAA (5).

One of the first LCPs used for detection of amyloid formation was the anionic regioirregular PTAA, in this study[55] bovine insulin and chicken lysozyme were fibrillated and detected with PTAA. The result from these experiments showed PTAA bind to both native and insulin fibrils, but is able to distinguish the two forms. The absorption spectrum was red shifted upon binding to fibril, and the shift i.e. change in color was also detectable in solution by the naked eye. The conclusions from these studies were that conformational sensitive conjugated polythiophenes can be used as amyloid ligands and they can differentiate native and fibril protein structures.

As mentioned earlier, regioirregular polythiophenes may cause some experimental inconsistences, and the problem can be avoided by polymerizing symmetrical 
monomers. In a study from 2005 Herland et al. [56] showed the trimer based LCP, tPOW'T, displayed higher specificity and selectivity towards protein aggregates in vitro and AD plaques in vivo than monomer-based POWT. After these findigs a question arise; is the trimer-based polythiophenes more sensitive than monomer-based? To investigate this a library of four trimer-based LCPs were synthesized together with four corresponding monomer-based LCPs[24], four zwitterionic, two cationic and two anionic.

The trimer-based showed specificity for insulin fibrils but not for native insulin and these experiments verified the hypothesis that trimer-based polythiophenes have a higher potential as amyloid ligands than monomer based.

Åslund et al. now knew after these two studies that trimer based regioregular LCP had strong affinity and selectivity for amyloid like structures and that the backbone of the LCPs seems fairly important. The idea came up on testing the LCPs towards neurodegenerative diseases in vivo. So why not develop a new molecule, but this time with a well-defined structure, i.e. why not synthesize a oligomeric specie, that could pass the brain-blood-barrier, (BBB). In the following study, Åslund et al. synthesized three molecules, based on tPTAA backbone with a length of five thiophene units[54]. The structures synthesized were p-FTTA, p-FTAM and pHTAA, figure 13. The findings from the in vivo experiments were all of the probes bound to amyloid and two of the three probes passed the BBB, p-FTAA and pHTAA. Furthermore p-FTAA was compared to ThT, and it was shown that pFTAA could be used as a prefibrillar non-thioflavinophilic sensitive probe. The response when A $\beta 1-40$ fibrillation kinetic was monitored was earlier with p-FTAA than ThT fluorescence for A $\mathrm{A1}-42$ the fluorescence was the same, between the two. 

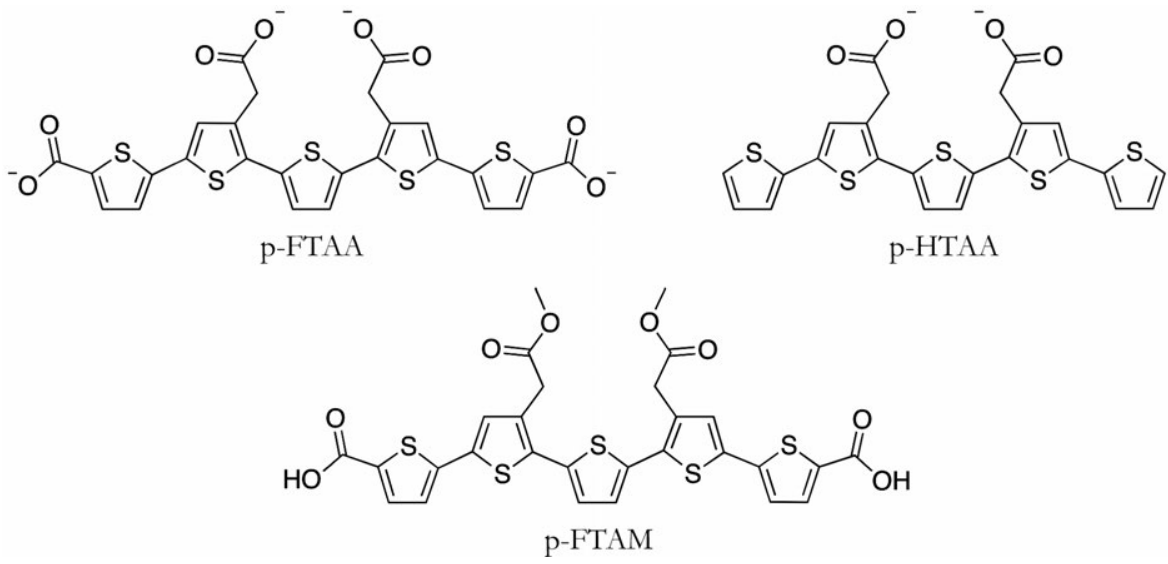

Figure 13. The chemical structure of p-FTAA, p-HTAA and p-FTAM.

So now a well-defined molecule that can distinguish not only native from fibrillated states, but also earlier stages of amyloid compared to ThT and small enough to pass the BBB was developed. Why not investigate the importance, if none, of the $\alpha$-position functionalities, and also see what happens if the length of the backbone is changed. In 2011, Klingstedt et al., Paper 1, performed a study of nine different LCOs, with thiophene units from four to seven in the backbone, and with hydrogens or formic acid as $\alpha$-positon functionalities[31]. The library was screened against recombinant A $\beta 1-42$ fibrils; all of them showed wavelength shifts when bound to fibrils. Previously studies has shown p-FTAA can distinguish A $\beta$ plaque from NFTs in AD patients[54], in this paper it was shown all LCOs could detect $A \beta$ plaque and NFTs in frozen brain sections, but the ligand requires five thiophene units or more and carboxylates for spectral discrimination of tau and $\mathrm{A} \beta$.

So let us just take a short brake and see what has been accomplished so far; A library of different LCOs have been developed, $\alpha$-position functionalities and length of back bone are important for selectivity. What will be the next step in the evolution of amyloid ligands?

After the conclusions from Paper 1, that small alterations in the thiophene backbone have impact on the properties as amyloid probe, and since a method for asymmetric synthesis of the LCOs were developed, why not use this asymmetry and functionalize the LCOs orthogonally and investigate if there could be other possible complementary techniques to study LCO and amyloid interactions. 
The idea to attach the LCO to a surface and use it as a capturing agent in an SPRset-up then came up. This first idea was to functionalize q-FTAA, seen in figure 12, with a thiol linker, immobilize the molecule onto a gold surface and then evaluate the binding capacity to amyloid fibrils. This set-up did not work as well as planned, but it led ultimately to Paper 2, where instead of thiol-chemistry amide and click chemistry were used[57]. In this paper we saw that it was possible to attach the LCO onto a surface and it could still capture amyloids. The conclusions from paper 2 were that we had developed a method that could be developed further towards a plausible diagnostic lab-on-a-chip application and that the interaction LCO-amyloid can be investigated with other techniques than fluorescence spectroscopy.

After paper 2 we wanted to investigate the LCOs as diagnostic tools further and as reported in Paper 3, LCOs were functionalized with specific isotopes and evaluated as PET-ligands. Three different LCOs were synthesized and radiolabeled. The result from these studies showed that radiolabelled LCOs could potentially be used as PET-ligands for clinic diagnostics of systemic amyloidoses. The findings in Paper 2 and 3 will be discussed in more detail later on. 


\section{METHODOLOGY}

\section{Organic Synthesis}

The LCPs and LCOs are synthesized according to two different synthetic pathways, polymerization and step-by-step synthesis. There are basically only three different reactions needed from the organic chemists' toolbox to synthesize LCOs, these reactions are: halogenation, carbon-carbon coupling and deprotection as seen in figure 14. The method used for the synthesis of LCPs is oxidative $\mathrm{Fe}^{3+}$-catalyzed polymerization and would not further be discussed.

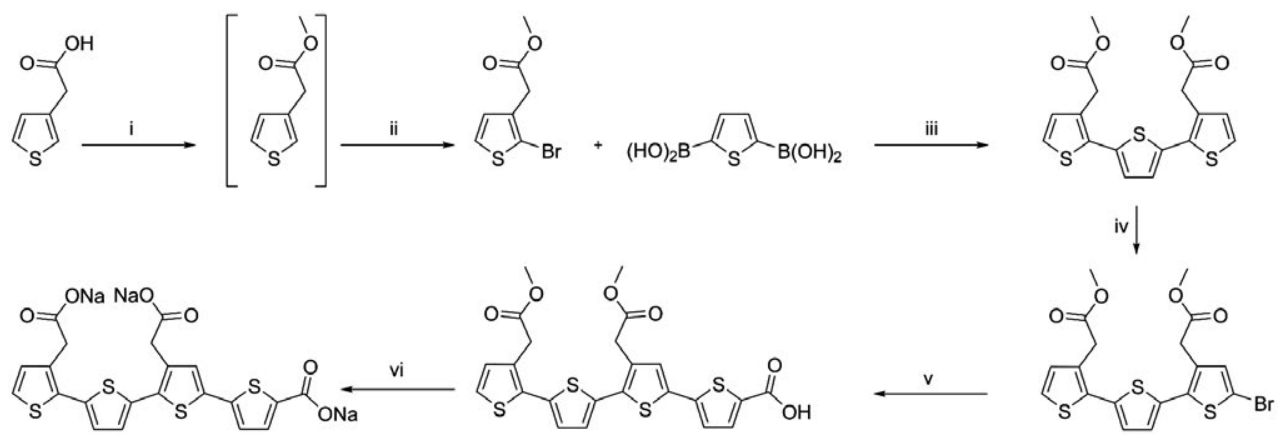

Figure 14. Reaction pathway for synthesis of LCOs, showing; bromination (ii and iv), carbon-carbon coupling (iii and v), and deprotection (vi). Here is the synthesis of asymmetric q-FTAA shown.

\section{Carbon-carbon coupling}

There are a lot of carbon-carbon (C-C) bond forming reactions in organic synthesis e.g. aldol[58]-, Diels-Alder[59]-, Heck[60,61]-, Wittig[62] and Grignard[63] reaction. The most common $\mathrm{C}-\mathrm{C}$ bond formations between aromatic compounds are the Suzuki[64,65], Stille[66] and Ullman[67] reactions. Suzuki and Stille couplings are palladium-catalyzed, and the first named reaction is the most common cross coupling nowadays. The traditional Ullman reaction is copper catalyzed, requires rather harsh conditions, with high temperature, and give poor yields. Even though there, recently, been some alterations made to the Ullman reaction, like using palladium as the catalyst and milder reaction conditions the yields are still only moderate to poor[68]. 


\section{Halogenation}

Halogenation means that hydrogen atoms in an organic compound are substituted to halogens[69]. There are several halogenation reagents to choose from, e.g. $\mathrm{HBr}$, $\mathrm{Br}_{2}, \mathrm{I}_{2}, \mathrm{SnCl}_{4}, \mathrm{NBS}$, NIS.

The reactivity order of the halogens in halogenation reactions is the following: fluorine and chlorine are more electrophilic and therefore more aggressive halogenating agents: bromine is weaker than the two, and iodine is the least reactive of them all. The order is reversed in dehydrohalogenation reactions meaning iodine is the most easily removed species. As mentioned before, a thiophene is an aromatic compound, and goes through the electrophilic aromatic substitution with halogenating reagents[70]. In our group we almost exclusively use $\mathrm{N}$-bromosuccinimide (NBS) as halogenating reagent. Attempt have been made with $\mathrm{HBr}$, but since we only want mono- or dibrominated compounds i.e the $\alpha$ positions brominated and since it is very easy to over brominate with $\mathrm{HBr}$, we have skipped that pathway. We have over the years developed a method for selective and controlled bromination of our thiophene compounds. By adding a scarce equivalent of NBS dissolved in DMF small portions to the cooled solution of substrate, the reaction can be controlled in the way that a mono-brominated product predominately is formed.

\section{Suzuki Coupling}

The most common way to create a carbon-carbon bond today is to use the Suzuki [64,71] or Stille cross-coupling[66]. These two reactions are palladium-catalyzed and the mechanism can be described as a three-step cycle consisting of oxidative addition, transmetalation and reductive elimination, as described in figure 15. The Suzuki reaction couples a halogenated substrate and an organoboronic acid or ester in the presence of base, whereas the Stille reaction use stannyl compounds instead of boronic derivatives. In the case of the Suzuki reaction, a base must be added to activate the boron atom to ease the transmetalation step, and by varying the base the reaction conditions can be optimized[72]. The Suzuki cycle starts with the oxidative addition step, were $\operatorname{Pd}(0)$ is inserted into the $\mathrm{R}-\mathrm{X}$ bond, giving $\operatorname{Pd}(2)$ as an intermediate, with $\mathrm{R}$ and $\mathrm{X}$ as ligands, transmetallation means ligand exchange between $\operatorname{Pd}(2)$ and a metal, here boron, which means that the R'-group on boron is coordinated to the $\operatorname{Pd}(2)$-complex. Th cycle ends with the reductive elimination, $\operatorname{Pd}(2)$ is reduced to $\operatorname{Pd}(0)$, and the two organic-groups are coupled together and eliminated as R-R', and the new $\mathrm{C}-\mathrm{C}$ bond is formed.

In our group, $\mathrm{K}_{2} \mathrm{CO}_{3}$, has turned out to be the most convenient choice, but the mechanism is still not fully understood. Due to negative health and environmental 
risks working with tin compounds, the Suzuki coupling is the preferred choice today. The palladium catalyst normally used in our lab is a electron-rich $\mathrm{N}$ heterocyclic carbene (NHC) compound called PEPPSI ${ }^{\mathrm{TM}}$-IPr[73,74], see figure 15. These NHC ligands have shown to be very beneficial for the Suzuki-coupling[75].

Our first Suzuki reaction protocol for synthesis of LCOs involved microwave irradiation in a sealed vessel under argon. The advantages with microwave chemistry are milder reaction conditions, higher yield and higher selectivity, accelerated reaction rate and lower energy usage[76]. The disadvantage that we encountered was a difficulty to scale up the reactions, limiting the reaction volumes to $5 \mathrm{~mL}$. We then developed a method to run the reactions in round bottom flasks in the fume hood instead. What we gained was the possibility to do the reaction in gram scale instead of the 100-200 mg reactions that was the limit in the microwave vessel used at the time. We did not loose anything in yield, and in my humble opinion going from up to ten time-consuming microwave reactions to just one in the fume hood, was the biggest gain.

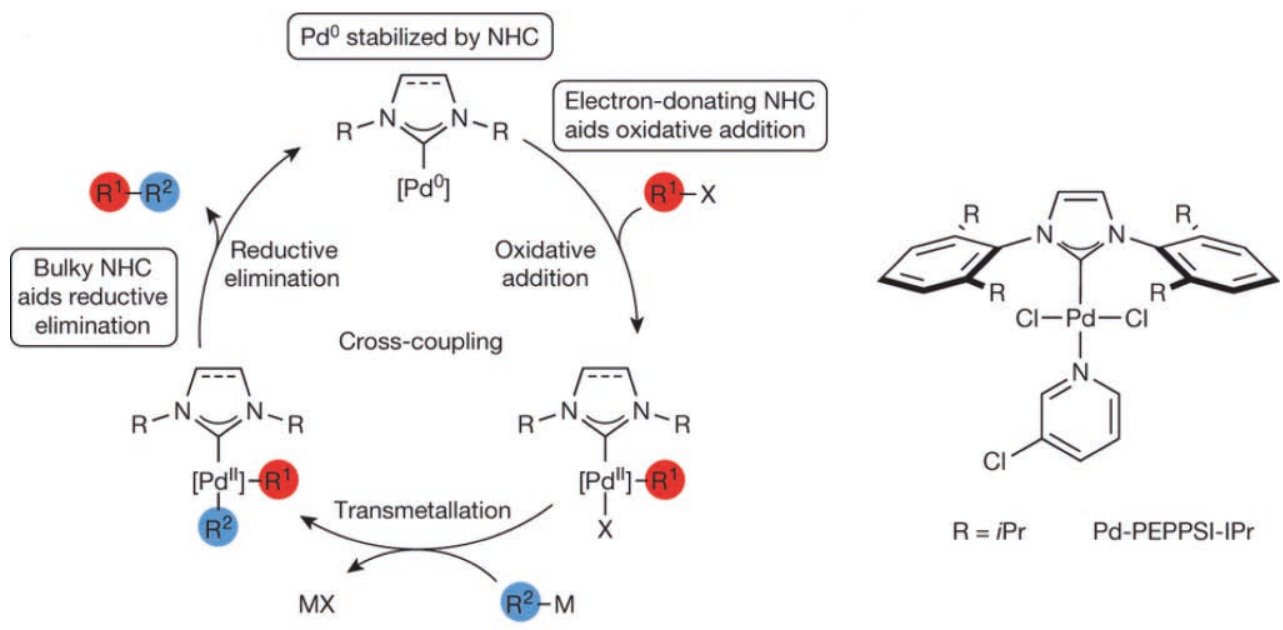

Figure 15. Mechanism of Suzuki cross-coupling, using PEPPSI-IPr as Pdcatalysts. Reprinted with permission from Nature Publishing Group[77]

\section{Click Chemistry}

In 2001 K.B Sharpless [78]introduced the term "click chemistry" to describe reactions that are high yielding, wide in scope, give easier purification steps, (often without chromatography), are easy to perform, stereospecific, and can be performed in benign solvents. A lot of reaction types fulfill these criteria, e.g. nucleophilic ring opening reactions of epoxides and aziridines, non-aldol type carbonyl reactions, such as formation of hydrazine and heterocycles, oxidative 
formation of epoxides and thermodynamically-favored reactions which lead to specifically one product. When organic chemists talk about click chemistry, the reaction they think of first is probably the azide-alkyne cycloaddition, which selectively gives 1,2,3-triazoles, a reaction termed Huisgen's 1,3-dipolar cycloaddition.

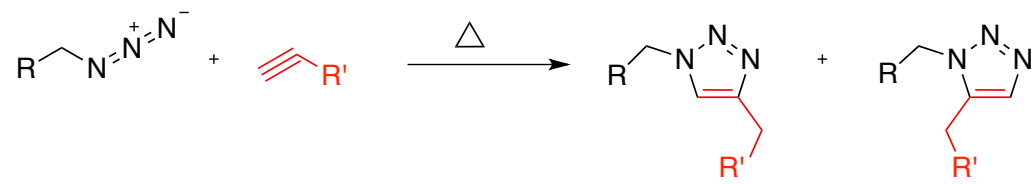

Figure 16. Reaction scheme depicting Huisgen's 1,3-dipolar cycloaddition.

The reaction depicted above, requires high temperature, and often give rise to regioisomers, if asymmetrical alkynes is used which is why the classical 1,3-dipolar cycloaddition fails to be termed a true click reaction. If instead, the reaction is carried out in the prescence of a copper-catalyst it turns into a true click reaction, which can be performed at room temperature and in aqueous solutions[79]. The copper-catalyzed reaction specifically gives 1,4-disubstituted regioisomers, and a later developed ruthenium-catalyzed reaction gives regioselective 1,5-disubstituted triazoles.
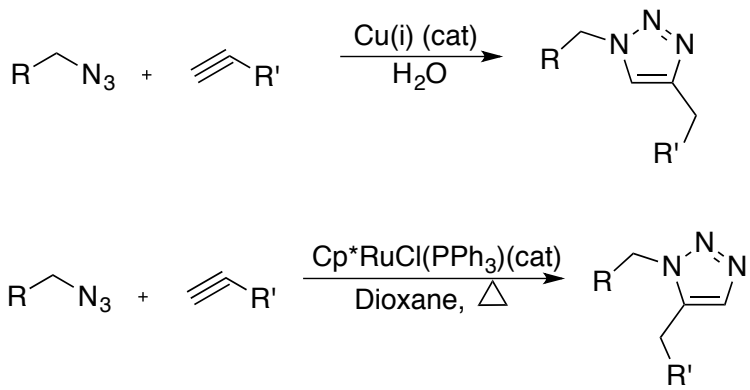

Figure 17. Reaction scheme depicting the copper- and ruthenium catalyzed regioselective cycloadditions.

Copper assisted click chemistry has enabled several applications in organic synthesis, material science, medicinal chemistry and molecular biology. The copper-catalyzed azide-alkyne cycloaddition (CuAAC) version has a reaction rate of $10^{7}$ to $10^{8}$ faster than the uncatalyzed 1,3-dipolar azide-alkyne cycloaddition. The reaction proceeds well in aqueous medium, works from $\mathrm{pH} 4$ to 12 , and are compatible with a broad range of functional groups. Purification is easily done 
without chromatography or recrystallization, filtration or extraction is often enough to get a pure product [79].

However, even though CuAAC is fast, simple, high yielding and reliable it still contains copper, though copper can have mild to severe cytotoxic effect[80], efforts have been made to avoid copper and go towards green chemistry. Bertozzi and Boons developed strained cyclooctynes, to replace the terminal alkyne and copper catalyst in the 1,3-dipolar cycloaddition. These cyclooctynes have an intramolecular strain and therefor reacts easily with azides without catalysts and at room temperature, and gives high yield[81-83]. The first[81] cyclooctyne developed, had a quite slow reaction kinetic compared with CuAAC, over the years other cyclooctynes with better properties have been developed. For instance, by adding electron-withdrawing groups such as fluorine[82] or synthesize a dibenzocyclooctyne moeity[83] and by replacing one carbon atom in the dibenzocyclooctyne ring with nitrogen [84,85], the reaction rate could be improved.
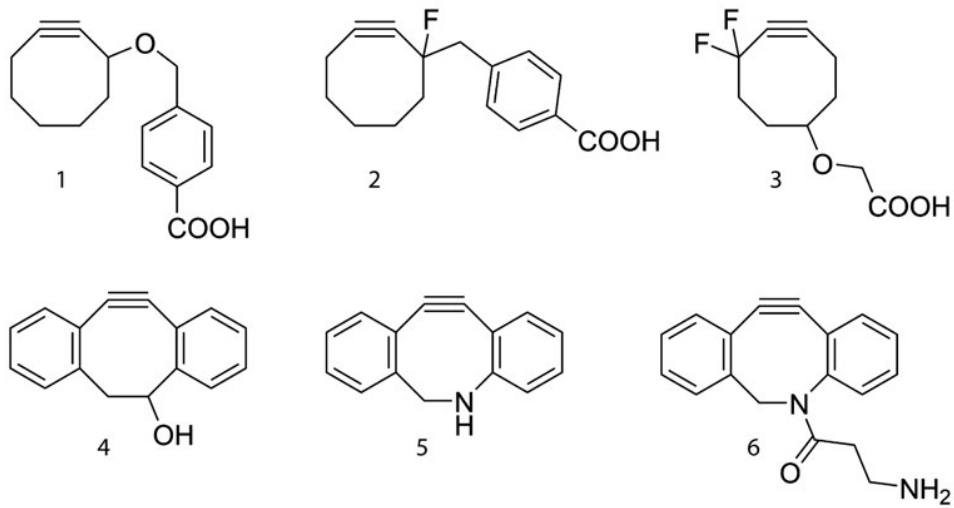

Figure 18. Chemical tructures of different cyclooctynes used in copper free click chemistry. 1) cyclooctyne[81], 2) fluorinated[86], 3) difluorinated[82], 4) dibenzocyclooctyne [83], 5) aza-dibenzocyclooctyne [84,85], 6) DBCO-amine used in Paper 2 and 4.

Why is click chemistry considered better than for amine chemistry? Why don't we use amide-coupling chemistry in Paper 2? Why use a click reagent that actually has an amine as functional group?

When using click chemistry with cyclooctyne, i.e. copper-free click the advantages is, that there is no need for a purification step, the affinity for azide and the triple bond is higher than that for amine and carboxylic acid, you do not need coupling reagents, you do not need a terminal alkyne, and you get higher yield. In Paper 2, 
when we used the dibenzocyclooctyne-amine, (DBCO-amine), we could have used normal amine-coupling chemistry, i.e. instead of a p-FTAA-azide, used a p-FTAAamine instead. We did synthesize an amine compound, but when the surface was functionalized with this molecule, we saw lower levels of binding compared to $\mathrm{p}$ FTAA-azide and less amyloid fibril were captured, (unpublished results). One explanation for this could be that every activated carboxyl group on the surface, which have a DBCO-amine, bind to a p-FTAA-azide, due to the high affinity between azide and alkyne and then give a higher yield of capture agent on the surface. In the p-FTAA-amine case it is possible that the coupling between amine and activated carboxyl groups on the surface is less sufficient, meaning decreased yield of capturing agent.

\section{Fluorescence}

Some molecules have a property called fluorescence, which means that they can absorb light of one color (wavelength) and emit light of another color (wavelength). The fluorescence phenomenon is therefore based on the property of molecules to absorb light at a particular wavelength and to subsequently emit light of longer wavelength after a brief interval. The Jablonski diagram, figure 18, is often used to visualize this process.

A molecule has a ground electronic state, a lower energy state $\left(\mathrm{S}_{0}\right)$, and higher excited energy levels $\left(S_{1}\right.$ and $\left.S_{2}\right)$. In these excited energy levels there are several vibrational states. When a molecule is excited by absorption of a photon, the molecule travels to a higher vibrational energy level in $\mathrm{S}_{1}$ or $\mathrm{S}_{2}$. The energy the molecule has gained is almost immediately released mostly as heat and the molecule falls down to $S_{1}$. When the molecule then falls back to the ground state some of the energy is released as a photon, or light with lower energy, i.e. higher wavelength, than from the start, this difference is called Stokes shift[87]. 


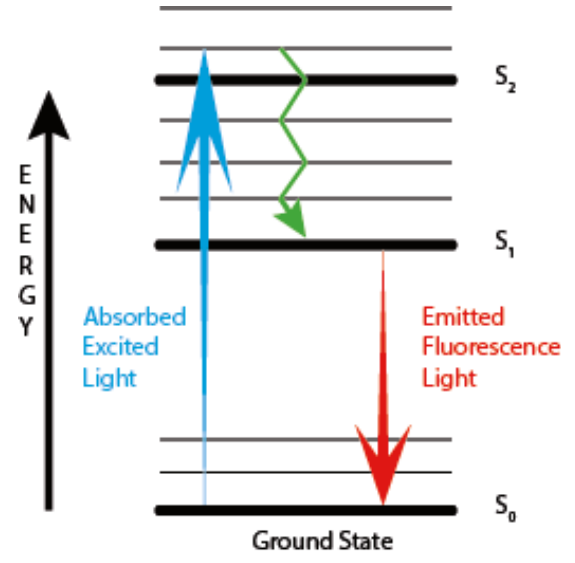

Figure 18. Jablonski energy diagram of fluorescence. The blue arrow represents absorption of light, the green represents vibrational relaxation from excited state $\mathrm{S}_{2}$ to $S_{1}$. The red arrow represents fluorescence to ground state $S_{0}$.

\section{Affinity studies using fluorescence}

In paper 2 we wanted to investigate binding affinity of LCOs to fibrils, which can be done by measuring the dissociation constant $\left(K_{d}\right)$ using e.g. fluorescence spectroscopy and SPR.

The $\mathrm{K}_{\mathrm{d}}$-value from fluorescence spectroscopy was determined by adding LCO to $\mathrm{A} \beta$-fibrils and the fluorescence signal was expected to change when the LCO interacted with the misfolded protein. The change in emission intensity was then plotted versus LCO concentration.

The following equation describes the binding of an analyte to a protein:

$$
\mathrm{P}+\mathrm{A} \longleftrightarrow \mathrm{PA}
$$

The dissociation constant $K_{d}$ is at equilibrium defined by

$$
K_{d}=\frac{[P][A]}{[P A]}
$$

Here $[\mathrm{P}]$ is concentration of free protein, $[\mathrm{A}]$ is concentration of free analyte and [PA] is the concentration of the PA complex. A low value of $K_{d}$ is characterized by high affinity. More specific, in the case of affinity measurement using fluorescence, the ratio 455/405 nm were plotted versus different concentrations of LCO. $455 \mathrm{~nm}$ is the excitation maximum of bound LCO and $405 \mathrm{~nm}$ unbound. 


\section{Surface Plasmon Resonance}

Surface plasmon resonance is a powerful optical technique for studying binding phenomena at a surface in real time. The SPR method is a sensitive method for detecting refractive index changes close to a gold-surface[88], and can be used to study affinity, kinetics and thermodynamics of protein-protein interactions[89]. One of the interacting molecules, the ligand, is immobilized onto a sensor-surface and the other, the analyte, is free in solution and injected over the surface.

Our interest in this method was to study LCO-amyloid interactions and to address the following scientific questions:

- Is it possible to study LCO-protein interaction by SPR?

- Can we measure kinetics and affinities and prove binding to amyloid?

- Is it possible to design better binding probes, i.e. evaluate functionalities and backbone lengths to get better binding and/or specificity?

- Is it possible to create a lab-on-a-chip?

Surface plasmon resonance occurs when polarized light passes through a prism with a specific angle and undergoes total internal reflection at a metal (gold) film and an external medium[90]. The incoming light excites electrons so called plasmons in the metal film, that propagates along the metal film-medium interface and the plasmons resonate. The plasmon absorbs the incoming light energy and a decrease in the intensity of the reflected light can be observed. This decrease is shown in figure 19 in the left graph, where reflected light intensity is plotted versus the angle of incidence, $\Theta$. When the refractive index at the metal film changes, i.e. the angle goes from I to II due to an analyte binding to the ligand; this change in angles can be measured. The change in refractive index, measured in response or resonance units (RU), is plotted as a function of time. In the set-up used in this work, a change of $\Delta \Theta_{s p}=0.0001^{\circ}$ corresponds to $1 \mathrm{RU}$ which can be converted to a mass change on the surface of $1 \mathrm{pg} / \mathrm{mm}^{2}$. 


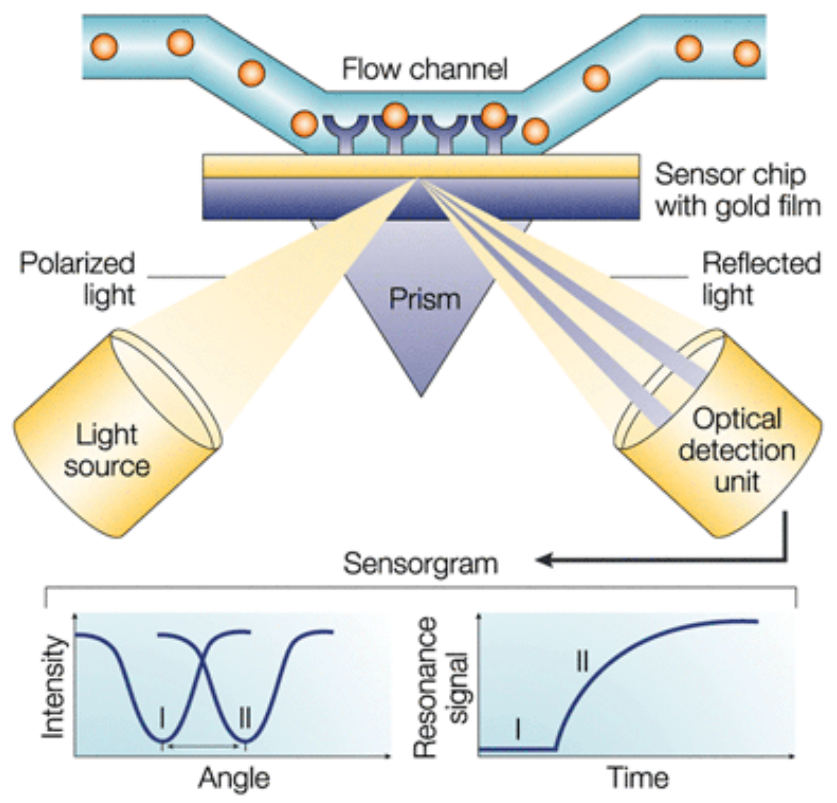

Figure 19. Schematic illustration of a Kretschmann configuration based SPR set up. The sensor surface is a gold film with immobilized ligand. As the analyte binds to the ligand, the refractive index changes and $\Delta \Theta_{s p}$ changes to a larger angle. This change in angle is the actual monitored signal, and the response over time gives the sensorgram. Reprinted with permission from Macmillan Publishers Ltd. [90]

The first experimental set-up, we employed was to immobilize the $A \beta$-fibrils directly onto the CM-5 chip as a ligand and then inject the "normal" LCO as analyte. We had several problems with this set-up, the first and most important was that we could not get a stable surface; we saw that by just running buffer over the flow channel we washed away our ligand. Attempts were made to covalently bind the native $A \beta$-peptide to the surface and then seed with $A \beta$-fibrils, although this did not solve the problem with the unstable surface. Another problem with this first set-up was that the LCOs are very small, (500-700 Daltons) in comparison to the fibrils, which leads to very small changes in the RU-signal even at high concentrations. But after changing to the successful system we developed later and what we learned from that, ideas has come to try the old system again, with some improvements.

An improved method was then developed, where the LCOs were immobilized on the surface, as a capturing ligand, and the amyloid was injected as an analyte. An azide functionalized LCO with a TEG- linker was synthesized and tested with 
good results, as we have shown in Paper 2. In this paper we shows that it is possible to study LCO-amyloid interaction using SPR, and we prove that there is selective binding to amyloid whereas native protein will not be captured by the LCO, figure 21. As shown in Paper 4 there are some differences between backbone lengths and functionalities, although additional studies need to be done, to fully elucidate these differences. Putting all these data together we foresee a possibility to use the described set-up as a lab-on-a-chip application.

In short, coupling of the azide functionalized LCOSs to the carboxylated dextran matrix[91] on the SPR-chip, was done as depicted in figure 20. The carboxylic acid on the dextran was activated with EDC/NHS and the alkyne-moiety used for the click chemistry, which contains an amine, was then coupled to the surface through the formation of an amide bond. This was followed by an injection of ethanolamine to block, or cap, any unreacted carboxylic acids. Finally amyloid ligand was injected, and coupled to the surface through a click reaction. The functionalized surface is thereby ready for measurement.

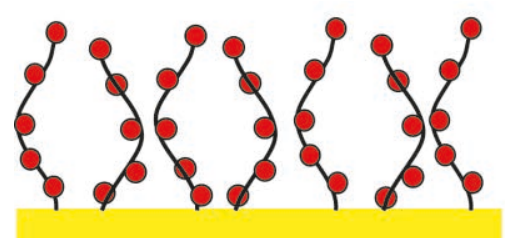

$\mathrm{COOH}$

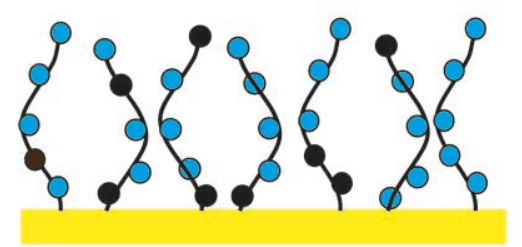

$\mathrm{HO} \sim \mathrm{NH}_{2}$
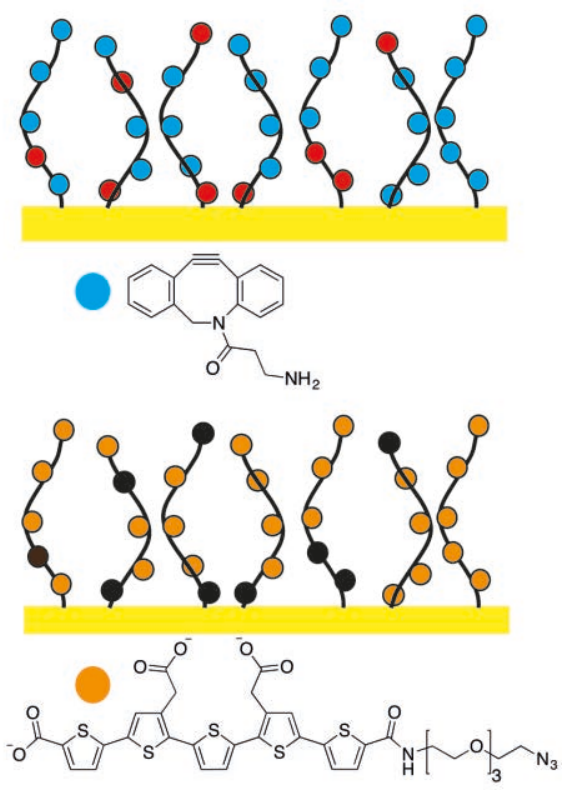

Figure 20. Schematic picture on SPR set-up. The surface was activated with DBCOamine, blue dots, capped with ethanolamine, black dots, and functionalized with LCO orange dots. 


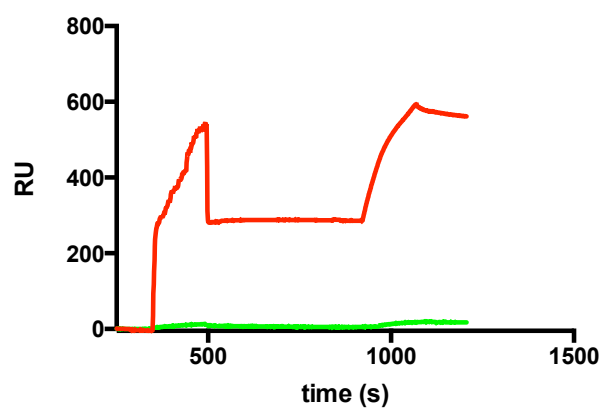

Figure 21. Proof of concept. The sensorgram showing $A \beta$ fibrils binding to $p$ FTAA-Azide (red) and native A $\beta$-peptide (green), which does not bind to $\mathrm{p}$ FTAA-Azide. The second peak is a specific A $\beta$ antibody (6E10), injected to verify the protein.

\section{Positron Emission Tomography}

Positron emission tomography (PET) is a molecular imaging method that uses radiolabelled molecules, PET-ligands. These ligands are labeled with rather shortlived radionuclides. PET is a noninvasive method and the distribution of ligands in tissue or organ can be detected in vivo using a PET camera[92,93]. The most common used radionuclides are carbon-11 and fluorine-18, with a half-life of 20.3 minutes and 109.8 minutes respectively[94].

In medical care, the most common PET-scan is visualizing cancer metastasis using a derivative of glucose, fluorodeoxyglucose (FDG). Since cancer cells have a higher metabolism and thereby a higher uptake of glucose, these cells can be detected and visualized in the scan. A method, now in use, has been developed where PET is used as a noninvasive diagnostic tool for the visualization of $A \beta$-deposits in the brain and a wide range of PET-ligands have been developed for the diagnosis of $\mathrm{AD}$, one of the most common is Pittsburgh compound B, (PiB). [51,95-98]

Our interest in PET-ligands started when it was shown that PiB, (See figure 10), also could visualize amyloid deposits in the heart[99], although there are no generally available PET-ligands for imaging of amyloid deposits in heart, pancreas, liver and kidney. LCOs however, have shown specificity for different types of protein aggregates such as aggregates in prion diseases, $\mathrm{AD}$ and systemic amyloidosis [24,54,100,101].

When looking at the structure of $\mathrm{PiB}$, and compare it to ThT, the idea came up; would it be possible to use LCOs as PET-ligands as well?

Since we have seen that LCOs often outdo ThT, this idea of making PET-ligands of LCOs seemed promising, see Paper 3. 
The first idea was to synthesize a compound without altering the molecular structure, i.e. use radiolabelled carbon, oxygen or hydrogen. Out of convenience the choice fell on using carbon-11 and the synthetic strategy was to introduce the radio ligand at the $\alpha$-position of the thiophene backbone using $\left[{ }^{11} \mathrm{C}\right] \mathrm{CO}$ (radiolabelled CO) as carbon source in a palladium mediated carbonylation reaction[102], but this reaction did not yield the carboxylic acid, very likely an amide was formed instead. Then a new synthesis route was tested, using $\mathrm{NH}_{4}\left[{ }^{11} \mathrm{C}\right] \mathrm{CN}$, and this reaction worked sufficiently, giving the thiophene an $\mathrm{CN}$ functionality instead of a carboxylic acid as intended (see figure 27). Two molecules were synthesized where ${ }^{11} \mathrm{C}$ was introduced, and as comparison a third molecule with ${ }^{18} \mathrm{~F}$ functionalized with a TEG-linker was synthesized and added to the study.

Here in Linköping, we synthesized the three cold reference compounds and collaborators at PET-Centrum Uppsala, performed the hot chemistry, i.e. radiolabeling of the compounds. 


\section{BIOSENSORS AND CLINICAL APPLICATIONS}

The general definition of a biosensor is "an analytical device used for detection of an analyte, that combines a biological component with a physiochemical detector" $[103,104]$. The two elements in a biosensor are; a sensitive element, that recognize a certain biological analyte and a detector element that transform the resulting signal to a readable signal. An example of a commercial biosensing system is the glucose sensor, used by diabetics daily worldwide to control glucose levels in blood.

How about LCOs and their capacity or future as biosensors? With the work in this thesis it might be possible to use the LCOs in a multi-array biosensing system Paper 2. LCOs clearly recognize a certain biological analyte; protein aggregates, and has an intrinsic detector element, fluorescence, that can transform the resulting signal to a readable signal. In addition, the azide functionalized LCOs also allow the development of a wide range of biosensing systems, such as lab-on-chip devices as well as the MSD format mentioned below. Thus, a variety of methodologies can be explored further with the aim of bringing the technique towards clinical use.

Another clinical application for the LCOs is non-invasive imaging and clinical diagnostic of protein aggregation diseases and in Paper 3, we present the first proof of concept for converting the fluorescent LCOs to radiolabeled tracers for PET imaging of protein aggregates. Although the results look promising, a novel arena for chemical improvement needs to be explored. More studies, with respect to toxicological studies and pharmacokinetics, need to be done and from this perspective the chemical evolution of LCOs will certainly continue... 


\section{FUTURE PERSPECTIVES}

During my time as a Ph.D. student I have become more and more interested in investigating the interaction between our thiophene probes using other techniques than are usually used in our group. This has made me realize that the work never ends, there is always one more interesting experiment that can be done.

One thing, I have looked into, is using MSD (Meso scale discovery protein assay), to detect and capture amyloids. This method is an ELISA-like method, using electrochemoluminescence, which is more sensitive than traditional ELISA. The initial experiments that I have done, showed promising results, in the sense that both the concentrations of LCO and detectable amyloid was much lower than detected using fluorescence and SPR. This work is only started and will, hopefully, be continued by others. MSD uses a capture antibody and a secondary detection antibody, and one idea is to synthesize a LCO that will work as both capturing and detection antibody. If we want to use LCOs as a lab-on-chip application, an MSD like approach would be an excellent option.

Another technique to measure interaction between the LCO and amyloid is ITC (Isothermal titration calorimetry), which is a good complement to SPR and fluorescence. ITC is used to determine thermodynamic parameters of an interaction in solution, such as protein-protein interactions and binding of small molecule to biomolecules [105] [106]. The initial experiments I performed were promising, although it was apparent that the concentration of amyloid was too low since the interaction reached saturation within the first couple of injections. An apparent $\mathrm{K}_{\mathrm{d}}, \sim 150 \mathrm{~nm}$, was estimated, using the limited set of data, which is in the vicinity of the $K_{d}$ 's measured with SPR and fluorescence (8 and $10 \mathrm{nM}$, respectively). Optimization of concentrations and injection volumes will make it possible to measure the thermodynamic parameters with greater certainty, and shed valuable light on the interaction of the LCOs and amyloid fibrils.

DSC (Differential scanning calorimetry) is a method used to study thermodynamic stability, folding mechanism and ligand binding to a protein[107]. Using this method we measured the thermal stability of both the amyloid in solution and of the LCO-amyloid complex. These experiments were inconclusive, since the thermal denaturation occurred at close to $130{ }^{\circ} \mathrm{C}$ which is the temperature limit of the DSC at the institution, but there were a clear difference between the amyloid and the complex. The melting point $\left(\mathrm{T}_{\mathrm{m}}\right)$ of the amyloid was roughly $128{ }^{\circ} \mathrm{C}$, whereas the $\mathrm{T}_{\mathrm{m}}$ ) of the LCO-amyloid complex was $130{ }^{\circ} \mathrm{C}$ or higher indicated that the LCOs adds stability to the amyloid. 
Two molecules, one nonamer (9-units) and one undecamer (11-mer) were synthesized, and they were never fully tested. It would be interesting to see if their properties are more comparable with PTAA (LCP) or with our LCOs. Another thing to investigate would be to mix LCOs, i.e. make a conjugate of two different LCOs. We have previously shown that double staining, with two different LCOs, makes it possible to distinguish maturation of fibrils[108]. I think it would be interesting to see if we can use two LCOs as a conjugate and compare that to the double staining. 


\section{SUMMARY OF PAPERS}

\section{Paper 1}

Previous studies has shown that a symmetrical, well-defined LCO with five thiophene units and four carboxylic groups could discriminate $A \beta$ plaques from NFTs and detect non-thioflavinophilic A $\beta$ species [54]

In paper 1 the aim was to design and synthesize a library of structurally diverse LCOs with different backbone lengths and $\alpha$-position functionalities. The library contained nine LCOs with backbone lengths from four to seven thiophene units and with carboxylates or hydrogen as functionalities at the $\alpha$-position. In the paper we reported a synthesis pathway to synthesize asymmetric oligothiophenes. The compounds were then evaluated in vitro in an A $\beta 1-42$ fibrillation assay and the spectral discrimination of $A \beta$ plaques from NFTs in human brain sections were studied.

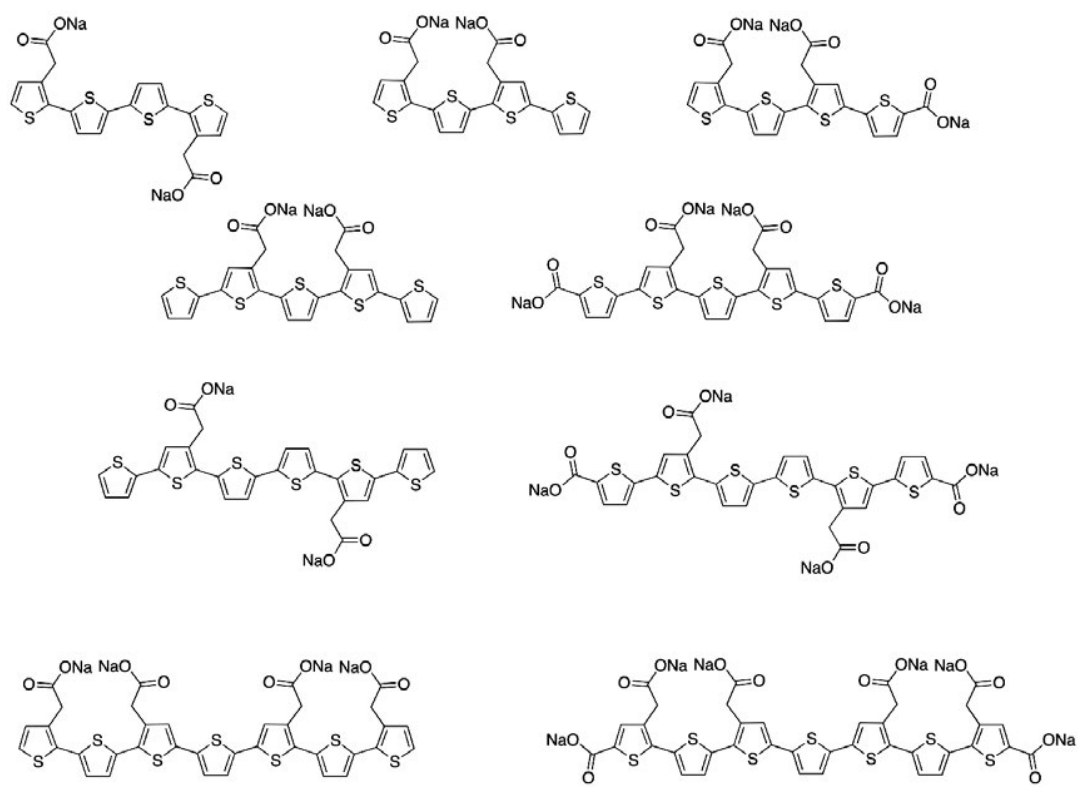

Figure 22. The structures of the nine LCOs in the study, depicted as sodium salts.

All LCOs showed selective binding to protein fibrils (recombinant A $11-42$ ), and the length of the backbone was dependent on early non-thioflavinophilic detection. The fibrillation assay showed that tetrameric LCOs had the similar kinetic as ThT, pentameric, hexametric and heptameric LCOs had an onset about 300 minutes earlier than ThT. 

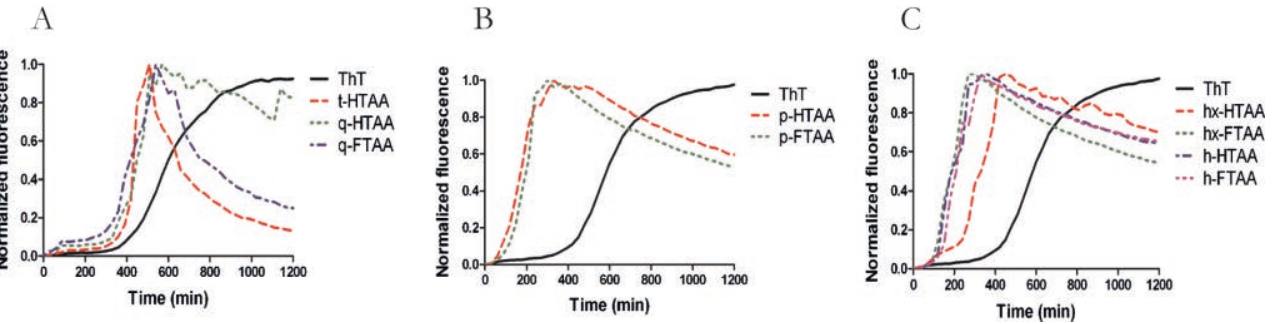

Figure 23. The fibrillation kinetic of A $\beta 1-42$ monitored by fluorescence from ThT and the different LCOs. Reprinted with permission from the Royal Society of Chemistry[31].

One explanation why the tetramers and ThT have a similar kinetic curve could be that they are similar in size.

When the brain sections were stained with the library, all LCOs showed specific binding to aggregated tau or $A \beta$. But to achieve a spectral discrimination between tau and $A \beta$, the LCO backbone need to be at least five units long, and have a carboxyl group at the $\alpha$-position.

The conclude paper 1; A small design modification in the LCO structure have large impact on their properties as amyloid ligands. By alteration of backbone length and $\alpha$-position functionalities, the optical properties and protein aggregate detection abilities changed.

\section{Paper 2}

In paper 2 we present the synthesis of an azide functionalized pentameric oligothiophene, p-FTAA-Azide, which allows for attachment onto a surface by copper free click chemistry.

The scientific questions we wanted to address where;

- Is a functionalized oligothiophene still selective towards protein aggregates?

- When attached to a solid support can the LCO capture and detect protein aggregates?

- Is it possible to use another technique than fluorescence microscopy to detect protein aggregates?

The first thing we wanted to look into was to compare p-FTAA-Azide and pFTAA, regarding their optical properties. Absorption (B), emission (C) and 
excitation (D) spectra were recorded using plate reader, figure 24. As seen the pFTAA-Azide showed a bit more red shift, (absorption maxima $422 \mathrm{~nm}$ ) than pFTAA. When excited at $420 \mathrm{~nm}$, the p-FTAA-Azide was also shifted to the red, emission maximum $564 \mathrm{~nm}$, compared to $545 \mathrm{~nm}$ for p-FTAA, notice also the absence of the remarkable double-peak in the p-FTAA-Azide spectrum. Interestingly enough there is no difference in the excitation spectra (D). All these small changes in shift and lack of double-peak gives a indication that p-FTAAAzide shows a more planar conformation than p-FTAA, due to the tetra ethylene glycol spacer. These experiments showed that p-FTAA-Azide bound to A $\beta$ 1-42 fibrils in the same manner as p-FTAA in solution.

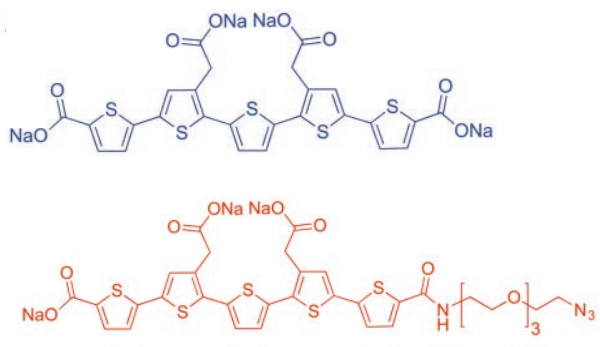

C

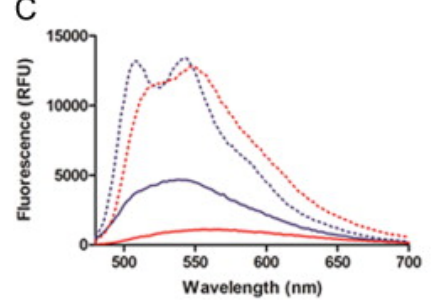

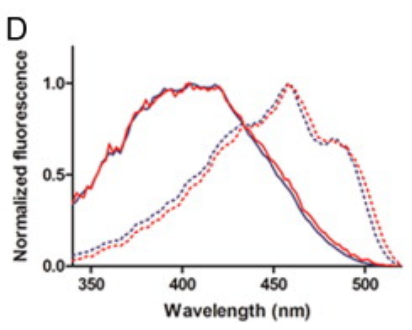

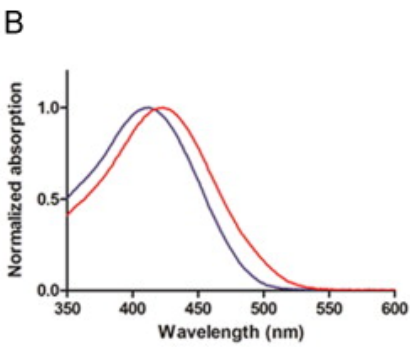

$\mathrm{E}$

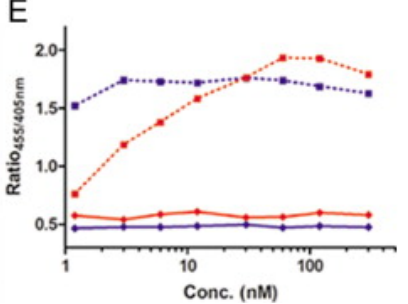

Figure 24. The chemical structures of p-FTAA, (blue) and p-FTAA-Azide, (red). B) Absorption spectra of p-FTAA (blue) and p-FTAA-Azide (red). C) Emission spectra of p-FTAA (blue) and p-FTAA-Azide (red), solid lines in buffer and dotted lines mixed with A $\beta$ 1-42 fibrils D) Excitation spectra of p-FTAA (blue) and p-FTAAAzide (red), solid lines in buffer and dotted lines mixed with A $\beta$ 1-42 fibrils. E) Binding curve showing the ratio, 455/405 nm, of the intensity of the emitted light at the respective excitation maximum, $455 \mathrm{~nm}$ (bound dye) and $405 \mathrm{~nm}$ (unbound dye) against different dye concentration. Different concentrations of p-FTAA (blue) or pFTAA-azide (red) in buffer (solid lines) or mixed with A $\beta$ 1-42 fibrils (dotted lines). Reprinted with permission from Elsevier B.V. [57] 
Next step was to determine a $K_{\mathrm{d}}$-value for the interaction between probe and protein using fluorescence. The definition of $K_{\mathrm{d}}$ is; "the concentration of free ligand where half the bindings sites are occupied", or "amount of free binding sites=amount ligand bound binding sites". The experiment was carried out as follows, the ratio $455 / 405 \mathrm{~nm}$, which is respective excitation maxima, $455 \mathrm{~nm}$ for bound probe and $405 \mathrm{~nm}$ for unbound probe was plotted versus probe concentration, the result was an apparent $K_{\mathrm{d}}$-value for p-FTAA-Azide of $10 \mathrm{nM}$.

To look into the accessibility of the azide for attaching the LCO to a solid support; a click chemistry protocol was tested to functionalize p-FTAA-Azide to carboxylated magnetic beads. First we treated the beads with EDC/NHS followed by coupling of DBCO-amine in a normal amine coupling chemistry to introduce a copper free clickable handle on the surface. To investigate non-specific binding we first incubated p-FTAA, the beads then were only visible in transmission mode, in fluorescence mode there was no signal (figure 25, A-C). When looking at the pFTAA-Azide functionalized beads, they were clearly visible in fluorescence mode, giving a strong green color (D-F). This gave us the conclusion that the click chemistry between DBCO-amine and p-FTAA-Azide was successful and could be used for attachment of azide-functionalized probes to a surface.

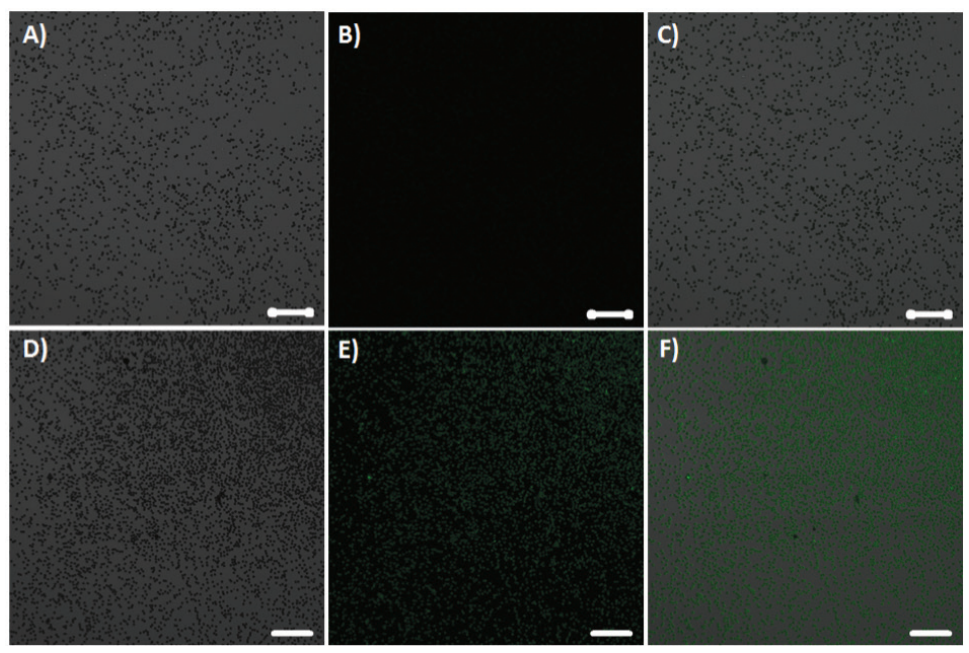

Figure 25. Images of magnetic beads treated with p-FTAA (A-C) or p-FTAA-azide (D-F). Transmission (A, D), fluorescence (B, E) and merged (C, F). Scale bars represent $50 \mu \mathrm{m}$. Reprinted with permission from Elsevier B.V.[57] 
To explore an LCO-based capturing assay, p-FTAA-Azide was evaluated in a BiaCore system, where the ligand was attached to a surface and a real time detection of the LCO-amyloid interaction with Surface Plasmon Resonance (SPR) was monitored. A gold chip with a carboxylated dextran matrix was treated with the same amine coupling chemistry as described above, to incorporate the cyclooctyne moiety on the surface. When the p-FTAA-Azide was injected over the surface a response of $100 \mathrm{RU}$ was obtained, and when p-FTAA as a control was injected, there was no response.

Then in vitro generated recombinant $\mathrm{A} \beta$ (M1-42) fibrils or freshly dissolved native recombinant A $\beta$ (M1-42) were injected. The p-FTAA-Azide immobilized channel gave a response of $300 \mathrm{RU}$ when fibrils were injected, the response from the native channel was nearly not noticeable, which verified that p-FTAA-Azide has not lost its specificity towards aggregated protein when attached to a surface. Finally when a specific $A \beta$ antibody (6E10) was injected, the response increased with another $300 \mathrm{RU}$, verifying the protein aggregate captured was containing A $\beta$-peptides. On the DBCO-amine functionalized surface, which works as a reference, no response were noticed when injected the two forms of $A \beta$ (M1-42) species. When fitting the binding curve to a Langmuir 1:1 model, an apparent $\mathrm{K}_{\mathrm{d}}$-value of $8.3 \mathrm{nM}$ was determined. This value was in the same order of magnitude as the fluorescent apparent $K_{d}$ estimated earlier.

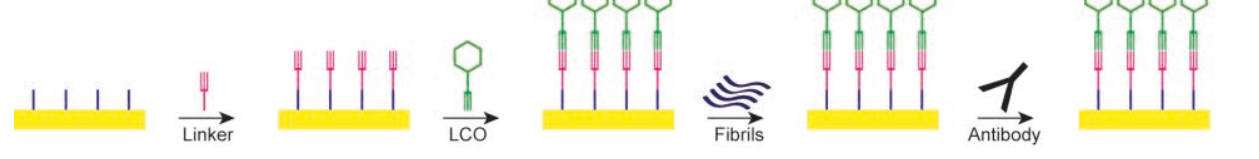

Figure 26. Schematic drawing of a multiarray based on LCO-capture/antibody detection. The activated dextran surface is functionalized with DBCO-amine and pFTAA-azide is covalently immobilized to the surface through copper-free clickchemistry. Upon injection of A $\beta$ (M1-42) fibrils the fibrils are captured by the LCO and to verify the nature of the aggregate entities an antibody (6E10) specific for $\mathrm{A} \beta$ is injected. Reprinted with permission from Elsevier B.V.[57]

To conclude, in paper 2 we have shown that p-FTAA-Azide, can be utilized for multimodal sensing of protein aggregates. We have also shown that an asymmetrical functionalized LCO has the selectivity and still can interact with 
protein aggregates. With the azide functionality we also have a simple tool to attach amyloid ligands to a solid support, again without disturbing the selectivity towards aggregates. This technique shows that together with an antibody it would be possible to identify different protein aggregates.

With SPR we also have the possibility to determine $K_{d}$ values for LCO-protein interaction, and thereby design LCOs with better or higher affinities for a certain protein aggregate.

\section{Paper 3}

In this paper we wanted to evaluate the LCOs as PET tracers, and the aim was to study local and systemic amyloidosis ex vivo and in vivo in real time. We also report the synthesis of three new LCOs.

The decision was to synthesize three different PET-ligands, one tetramer and two pentameric LCOs, the radionuclides chosen were carbon-11 and fluorine-18.
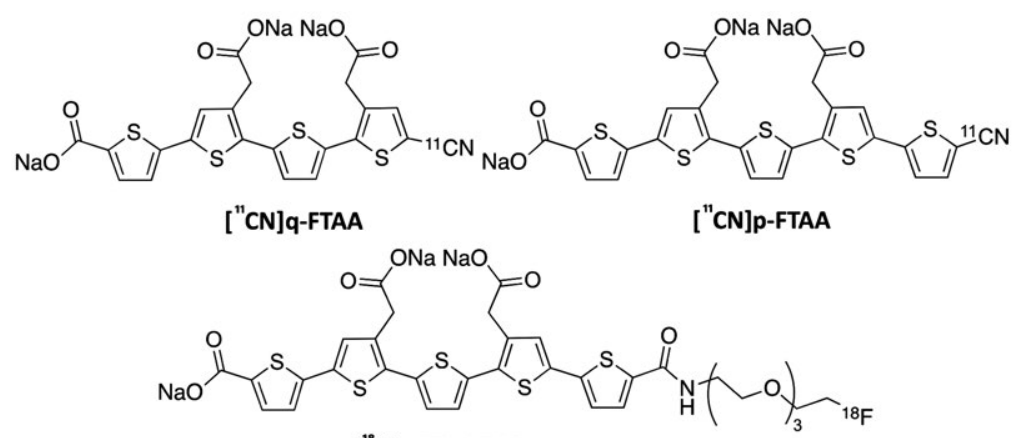

$\left[{ }^{18}\right.$ F]p-FTAA-TEG
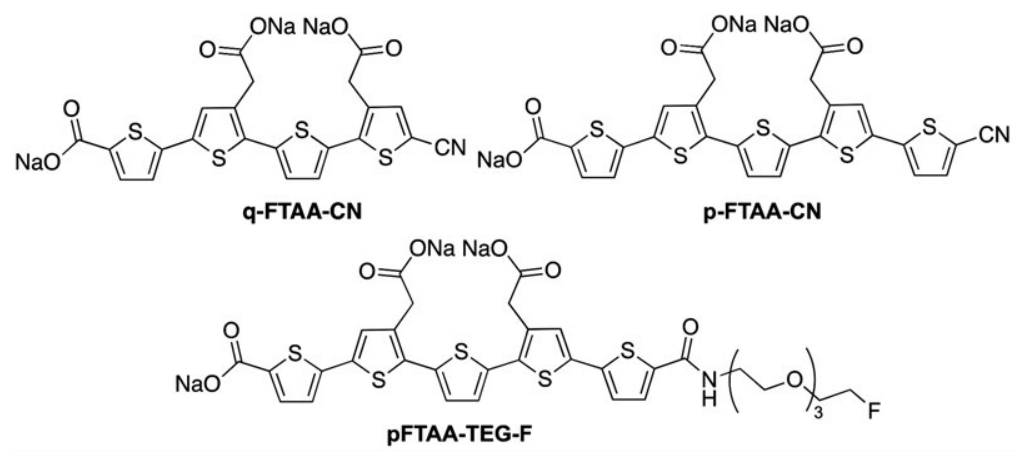

Figure 27. The structures of the three target PET-ligands (above) and the corresponding reference compounds (below). 
To verify the amyloid binding properties of the reference compounds tissue sections from patients diagnosed with systemic amyloidoses were stained with the reference compounds q-FTAA-CN, p-FTAA-CN and p-FTAA-TEG-F. All three LCOs showed specific binding to Congo red positive amyloid deposits from systemic amyloidosis patients with AA, AL, and ATTR, when excited at $458 \mathrm{~nm}$. The three novel LCOs showed a similar specificity towards protein aggregates as previously reported LCOs, verifying that the minor chemical modifications necessarily introduced for radiolabeling did not interfere with the amyloid binding potency of the dyes.
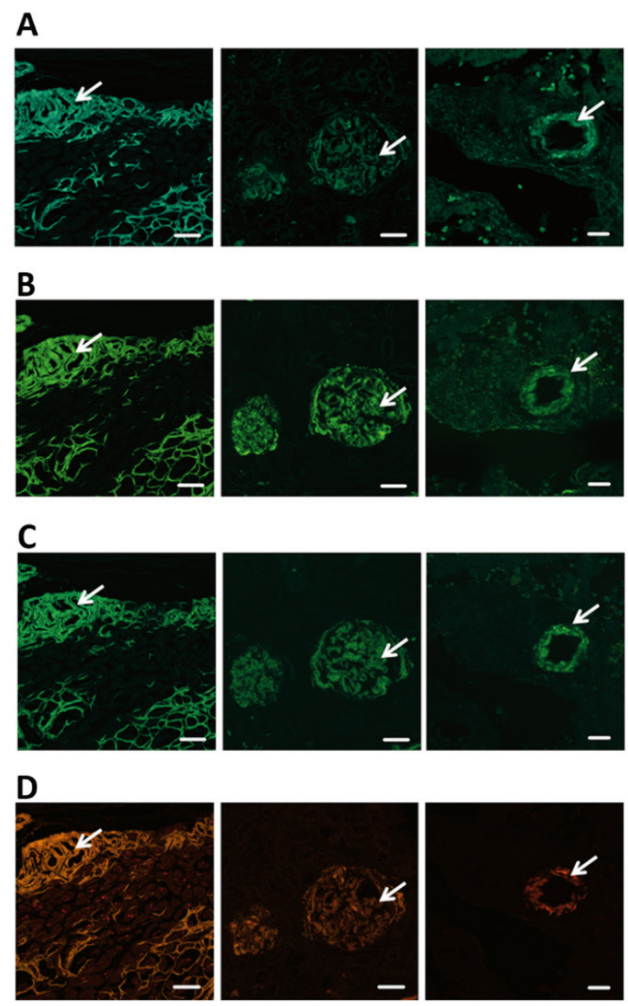

Figure 28. Fluorescence images of ATTR (heart) left column, AL (kidney) middle and AA (liver) right, stained with; A) q-FTAA-CN, B) p-FTAA-CN, C) p-FTAATEG-F and D) Congo red.

The results from the fluorescence microscopy were confirmed in homogenate binding studies with the radiolabeled compounds $\left[{ }^{11} \mathrm{CN}\right] \mathrm{q}-\mathrm{FTAA},\left[{ }^{11} \mathrm{CN}\right] \mathrm{p}-\mathrm{FTAA}$ and $\left[{ }^{18}\right.$ F]p-FTAA-TEG. PiB and p-FTAA were used as blocking substances. All three oligothiophenes derivatives showed high degree of specific binding to AL, 
ATTR, AA amyloid in human samples from heart, liver and spleen.

Finally, the three radiolabeled ligands were evaluated in vivo using healthy rats and a cynomolgus monkey to study pharmacokinetics and binding to non-amyloid containing tissue.

To conclude Paper 3, the three LCOs synthesized showed binding to amyloid deposits in heart, kidney and liver as shown by fluorescence microscopy. Further on, all the radiolabelled compound, $\left[{ }^{11} \mathrm{CN}\right] \mathrm{q}-\mathrm{FTAA},\left[{ }^{11} \mathrm{CN}\right] \mathrm{p}-\mathrm{FTAA}$ and $\left[{ }^{18} \mathrm{~F}\right] \mathrm{p}-$ FTAA-TEG showed specific binding to AL, TTR, and AA deposits from heart, spleen and liver. The competition or blocking experiment showed that LCOs could not be displaced by PiB, since they appear to have different binding sites.

\section{Paper 4}

In paper 4 we wanted to further investigate the multimodal detection methodologies for protein aggregates and here we are introducing three new azide functionalized molecules, an anionic tetramer and heptamer similar to p-FTAAAzide in Paper 2 and one new pentameric structure with methyl imidazole functionality. These molecules were evaluated regarding their optical properties and then explored in the same SPR assay as p-FTAA-Azide in Paper 2. In the paper the new ligands photo physical properties were compared to their non-azide functionalized counter part. The absorption characteristics differed compared to the non-functionalized molecules, all the azide-functionalized ligands follow the same trend, with a slightly more red shifted absorption maximum (figure 29-30). 

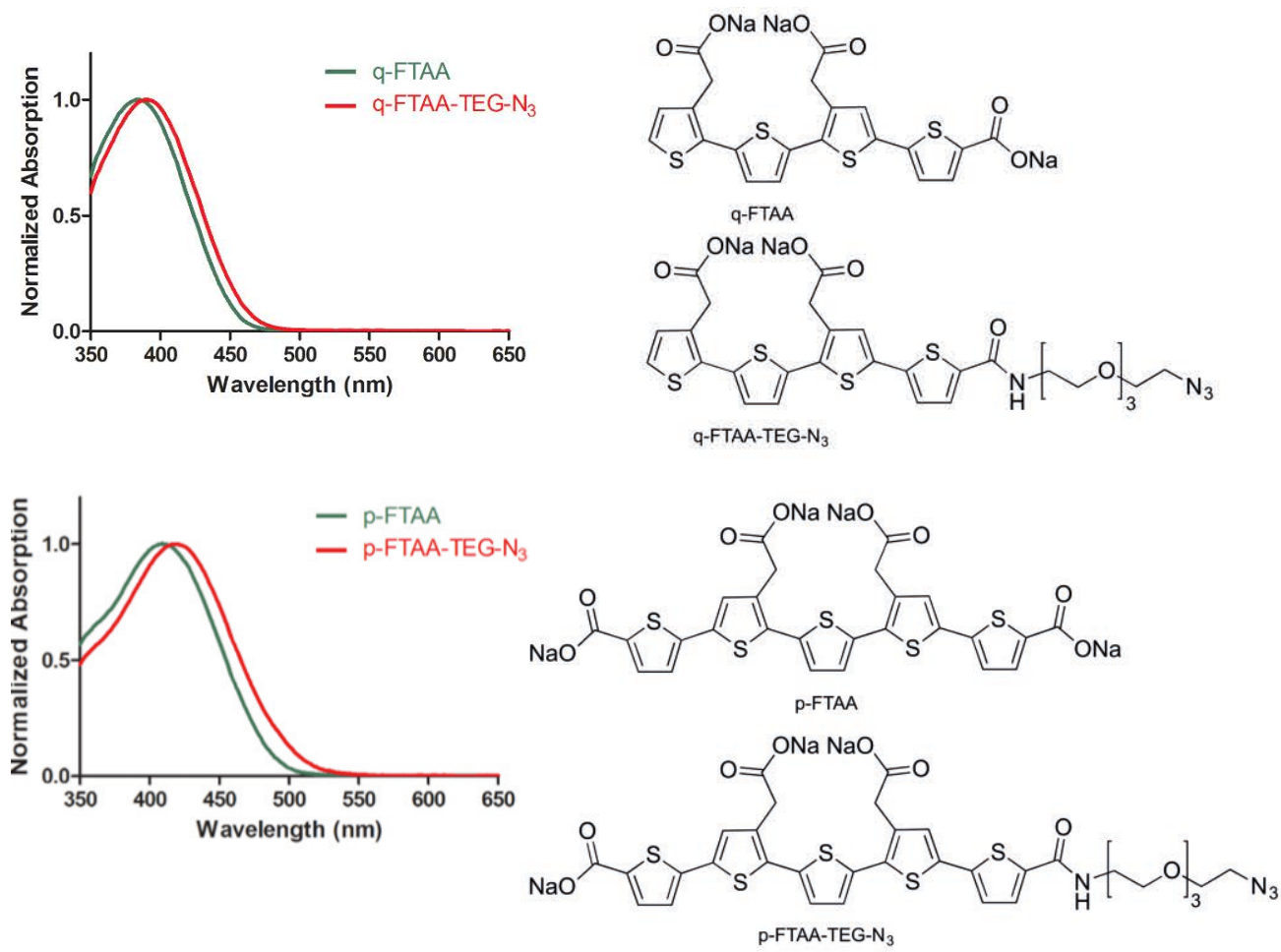

Figure 29. Absorption spectrum and chemical structure for the q-FTAA-TEGAzide and p-FTAA-TEG-Azide and their non-functionalized counterpart. 

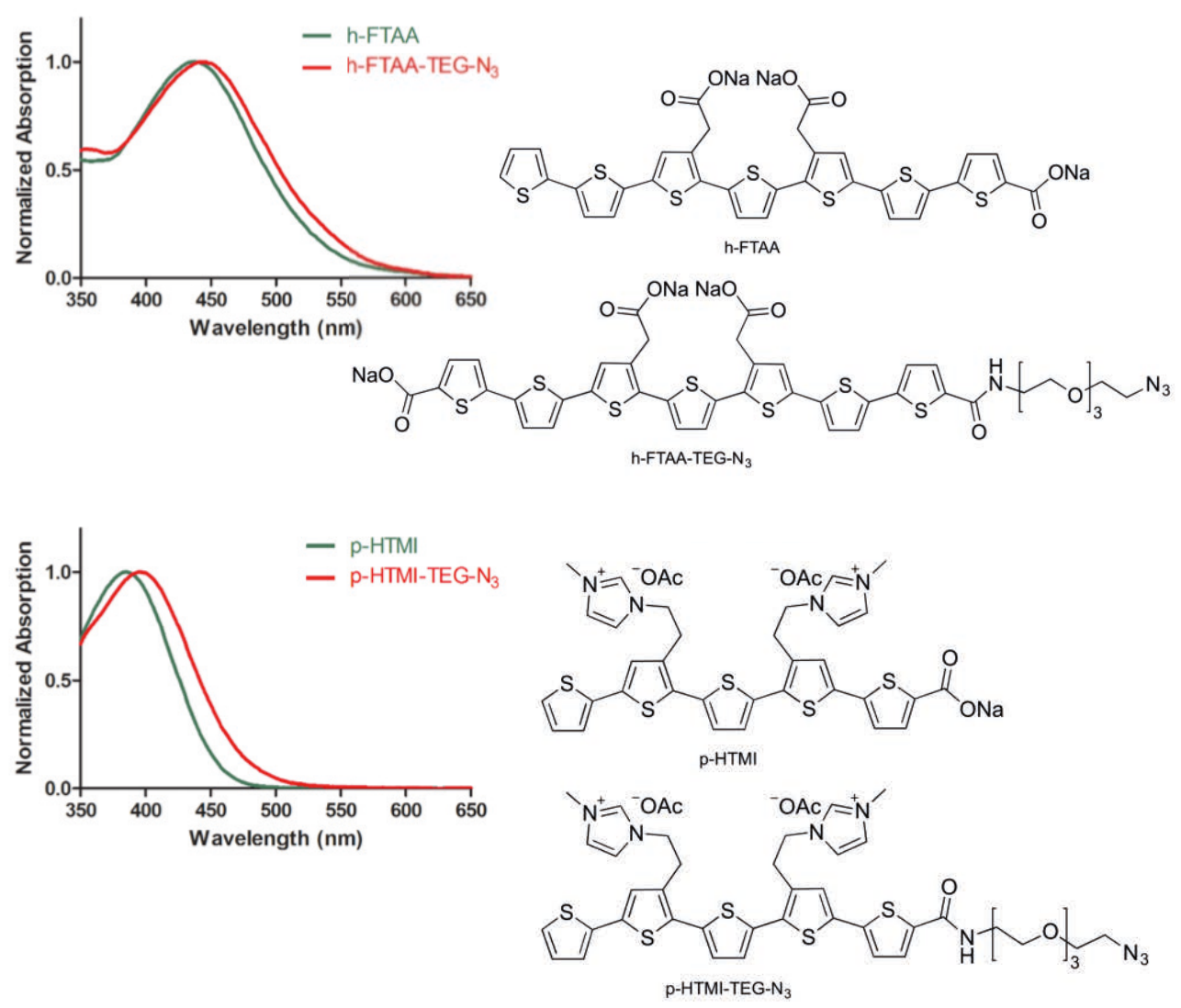

Figure 30. Absorption spectrum and chemical structure for h-FTAA-TEG-Azide and p-HTMI-TEG-Azide and their non-functionalized counterpart.

The TEG-azides were then mixed with recombinant $A \beta(M 1-42)$ fibrils and the fluorescence excitation and emission spectra were recorded. All of the molecules showed binding to the fibrils, excitation spectra were red-shifted and emission spectra slightly blue-shifted with increased intensity upon binding. As previously seen in Paper 2, when comparing the un-functionalized and the azidefunctionalized ligand, the characteristic double peak in emission spectras is less pronounced.

The ligands were then immobilized on a SPR chip and $A \beta(M 1-42)$ fibrils were injected. All four LCOs binds strong to fibrils and there are almost no dissociation, indicating a strong binding to amyloid fibrils. 

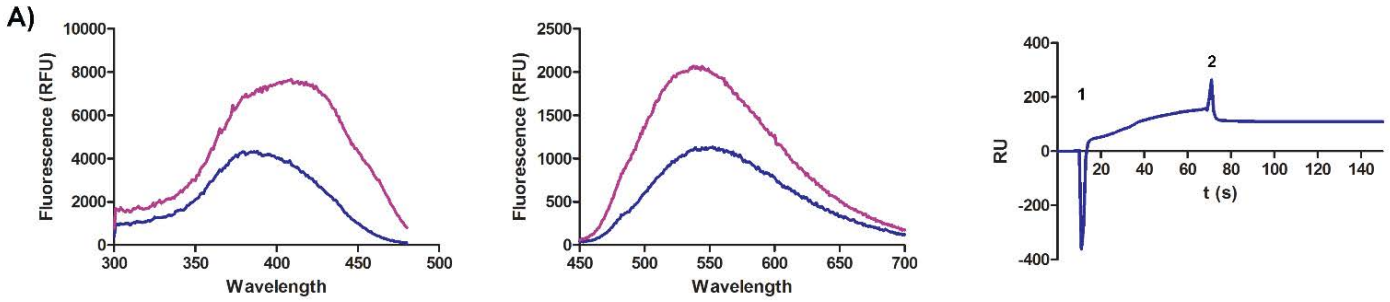

B)
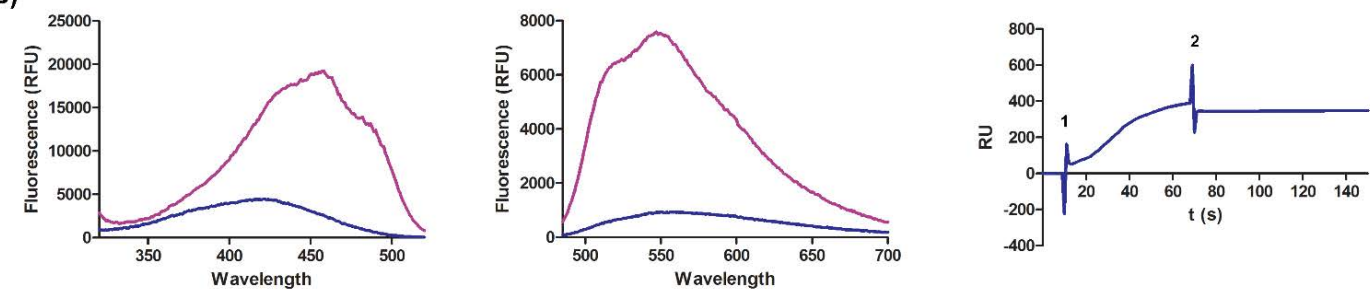

C)
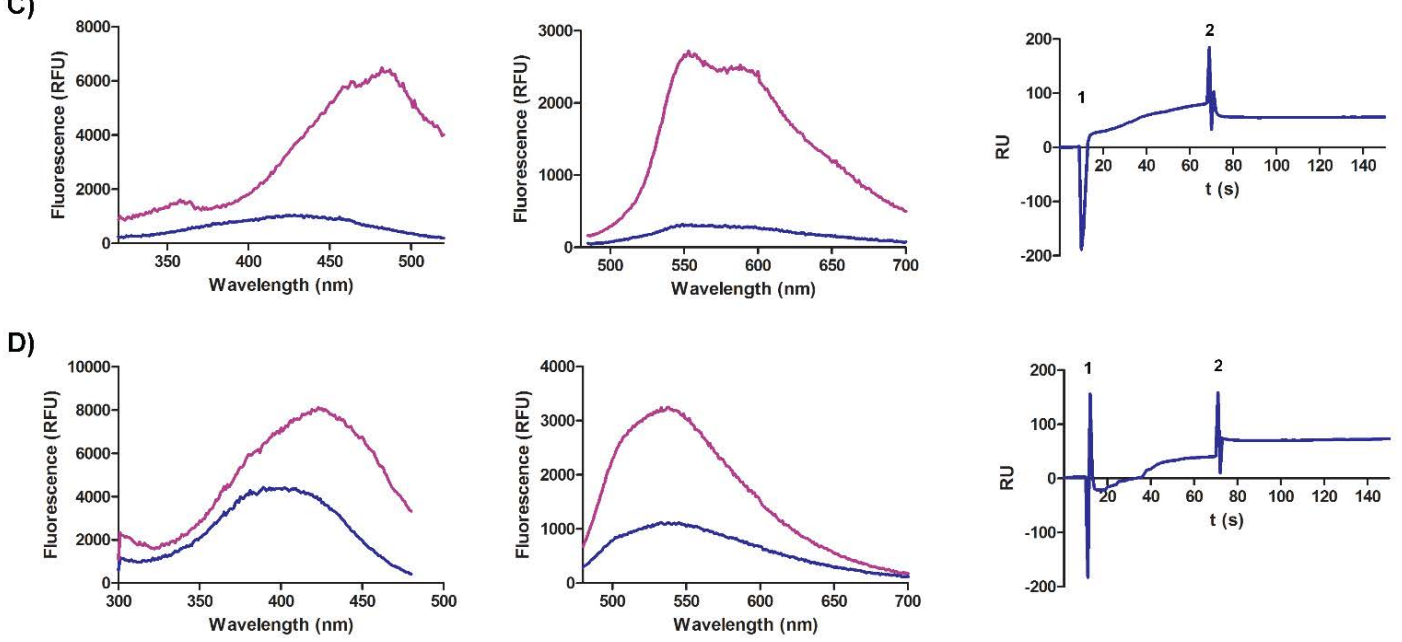

Figure 31. In the panel is photo physical and SPR data shown. Left panel is excitation spectra, middle emission spectra and right sensorgram. A, is q-FTAATEG-N $\mathrm{N}_{3}$, B) p-FTAA-TEG-N ${ }_{3}$, C) h-FTAA-TEG-N ${ }_{3}$ and D) p-HTMI-TEG-N . In $^{-}$ the sensorgram 1) indicates start of injection and 2) stop of analyte injection.

To conclude Paper 4, we introduced one pentameric LCOs with methyl imidazole functionality and functionalised with a TEG- $\mathrm{N}_{3}$-linker, and two LCOs similar to pFTAA-Azide in Paper 2, but with four and seven thiophene units respectively. All the molecule showed binding to recombinant $A \beta(\mathrm{M} 1-42)$ fibrils, both in fluorescence and in the reported SPR-set-up. 


\section{CONCLUSIONS}

From the work presented in this thesis the following conclusions can be drawn:

- The properties of the amyloid ligand are structure dependent. The conjugation length of the backbone as well as the $\alpha$-functionalities is of importance for selective binding to amyloid structures.

- When the $\alpha$-positions are functionalized with e.g. a TEG linker the photo physical properties slightly changes, but not the ability to detect amyloid.

- LCOs attached to a surface, still have its function and can detect and capture amyloid.

- The use of LCOs as PET-tracers seems promising, three different LCOs were tested, and they show binding to amyloid deposits in heart, kidney and liver.

- By this work here presented we have seen possibilities to develop new methods for detection and visualization of LCO-amyloid interaction. 


\section{ACKNOWLEDGEMENTS}

Så har vi då kommit till de där sidorna som många säger är de mest lästa $\mathrm{i}$ en avhandling, eller sidorna där känslorna får tala. En doktorandutbildning kanske kan liknas vid att föda barn eller att cykla runt en sjö. Min liknelse är i alla fall den att båda de här upplevelserna kan vara mer eller mindre, obehagliga eller smärtsamma, men efter ett tag så kommer man ju inte ihåg det, utan minns bara glädjen upplevelsen gav. Och så har det varit med min doktorandtid också, det har varit lite mycket ibland, men då är det skönt att det funnits människor runt omkring som gett energi och fått tankarna att gå mot rätt håll.

Och vissa av de här människorna vill jag nu rikta ett särskilt tack till. Nu kör vi!

En doktorandutbildning börjar med att någon vill anställa dig, och den som anställde mig var Peter Nilsson, som gjort de här åren till en fantastisk tid. Jag är glad att ha haft dig som handledare och förebild de här åren. Din förmåga att ta fram det bästa i en är jag väldigt tacksam över, och även all den energi ett snack med dig gett. Du har låtit mig arbeta och tänka fritt och alltid funnits där och stöttat. Din tro på mig har gett mig tro på mig själv.

Peter Konradsson, min biträdande handledare, organkorridorens store man, som inte bara vet hur en glykosidbinding ser ut, utan också vet att förmedla att livet också innehåller sport och musik. Insikten att delarna, jobb, träning och fritid behövs och kompletterar varandra, tar jag med mig från dig.

Tack till alla PetNi-gruppare, för goda samarbeten, diskussioner, gruppkonferenser, ni har alla lämnat spår efter er hos mig, stort tack till, Katriann, Linda, Marcus B, Bissan, Elisabet, Mathias, Hamid, Hanna, Karin, Rozalyn, Therese, Andreas, Jeff, Timmy, Mikaela.

Synd bara att jag inte kunde knipa pokalen på senaste PetNI-Mästerskapet.

Per Hammarström, för inspirerande samtal, ditt stora kunnande för att du alltid har tid att lyssna och för roliga projektidéer, och för din raka feedback. Jag är imponerad av ditt genuina intresse på varje presentation, och din förmåga att alltid hitta minst en fråga.

Nalle Jonsson, för alla kloka råd, relevanta frågor och för införandet av Nallefika, för att du till sist lät soffan komma dit där vi alla visste att den skulle passa så bra. Jag är inte anti-Nalle.

Andra hangaroundare till PetNigruppen är PelleTTR-gruppen, med Per $\mathbf{H}$, Sofie, Maria J, Maria T, Alexander S, Raul C, tack för intressanta samtal och 
presentationer, samt för roliga stunder på labbet. Det här med spädningar och pipett-tumme har varit en kul upplevelse.

Stefan Svensson, man kan inte ha genomfört en utbildning på Kemi utan att nämna något om studierektor Stefan, som så tragiskt rycktes bort allt för tidigt för några år sedan, jag vet inte vad han tyckte om mig, det får jag aldrig veta, liksom han inte får vet vad jag tyckte om honom. Och det är synd, han var en starkt bidragande orsak till att jag fortsatte läsa kemi efter mina 3 första år. Jag har saknat den torra humorn och det stora hjärtat under det ibland så buttra skalet.

Andreas Carlsson, min handledare på mitt första exjobb, tack för ditt stora engagemang på labbet, och jag minns ännu hur du sålde in syntesprojektet med "Suzuki-kopplingen, som förövrigt finns på en moped i Slaka"

Patrik Nygren, handledare på mitt andra exjobb, som lärde mig att kemi inte alltid är snabbt och enkelt, det kan löna sig att stå och tjura lite för plötsligt händer det och peptoiderna bara finns där. Vilken lycka när du kom tillbaka, både forskningsmässigt och cykelmässigt. Tack för alla goda diskussioner om masstransport, sadlar med hål, entalpier, ovala klingor, kemi och livet. Du har varit ett stort stöd, framför allt den här senaste tiden.

Lan, en av mina tidigaste vapendragerskor under, ex-jobb, stipendietider och en och annan Fredagspub.

Nallekorridoren, det är inte många kvar av oss nu, hoppas trivseln och alla glada skratt smittar av sig på nästa gäng som kommer, och att begreppet Nallefika inte försvinner, det har varit en härlig tid och miljö att vara i, Liza, Maria J, Martin, Karin, Patrik N, Lotta TT, Susanne, Anki, Nalle, Jutta, Mikaela, Anna, Rozalyn, Therese.

Lotta TT tack för alla tips och trix med BiaCore, avhandlingsskrivande och livet i stort. Jag älskar verkligen ditt "Om det inte är ett problem, gör det inte till ett problem".

Linda $\mathbf{H}$, mitt bollplank i stort och smått, diskussionerna har varit många och långa, tack för alla skratt, tips på program, outlines på posters, och inte minst för att du gav mig Raubtier.

Susanne för ovärderliga pratstunder om allt och inget under tidiga timmar, för att du alltid bryr dig och hjälper till med allt från krångliga reseräkningar, dumma sökvägar på LiUs hemsida till soffstölder. 
Kaffeklubben eller firandeklubben eller diktarklubben, det har druckits kaffe och öl, körts go-cart, spelats paintball och laserdome, det har diktats och pratats forskning det har ljugits en hel del runt det där bordet helt enkelt, tack för alla galna, glada minnen som jag kommer bära med mig länge, hoppas ni haft lika kul som jag; Anders, Jonas, Jonas, Karin, Lysholm, Peter, Sara, Katarina, Camilla, Staffan, Fredrik, Robban, Robban, Christoffer, Gunnar, Abdel, Viktor, Per, Lina, Linda, Skalle-Per, Abeni.

Och Lapp-Sara, jag lät dig alltid vinna.... Kat von B, ser fram emot att se dig med ditt nya racket.

Edvin och Matte T, tack för roliga stunder i lunchrum och runt kaffebord ni är ju i princip PetNi-gruppare, precis som Lilla $\mathbf{L}$ på $\mathrm{HU}$, vi har ju nästan lyckats med att adoptera dig, det är alltid lika kul när du kommer hit och delar med dig av glada energier och jag har inte gett upp hoppet om cykelturer runt någon sjö framöver.

Karin, min nuvarande kontorssambo, och mitt verkliga ljus i mörkret. Jag tror inte jag behöver säga så mycket, men utan dig hade det här inte varit lika kul. Det har hänt så mycket tillsammans med dig, bilturer i Danmark, bil-eller båtresor i Australien, snusprovning på VilleValla....Må äventyret aldrig ta slut!!

Therese BG Jr, tack för alla glada skratt, och diskussioner på BG-kontoret, jag har lärt mig mycket av dig, cellbiologi, kattlåderensande, ollies på skateboard i december, bara för att nämna några och det blev tomt utan dig, både på kontoret och utanför. Jag har försökt lära mig lite av din planeringsförmåga, men det är svårt Och nu efter eget skrivande förstår jag värdet av tystnad, men det är ju ännu svårare att vara just det.:)

Rozalyn, thanks for good and fun discussions over the years, I really miss you, sweetie, and it makes me happy seeing you happy at your new location so close but still so far, far away. But I believe a late night text still will reach you.

Maria J, du fick ta över lite av Helmforskans roll och den har du skött bra, det har blivit en hel del betting, detox, skrivarstugor, snack om sport, och gud vad jag vill göra de där MSD-försöken, typ dålig tajming och vara barnledig nu (:)

Till Lapp-Sara och Maria J, vad hände egentligen torsdag 151008?

Jutta, jag minns så väl den där dagen du kom in och presenterade dig på labbet, föga anade jag att skräcken skulle övergå i djupaste vänskap, tack för alla båtturer, diskussioner. Tillsammans med dig och Herr Doktor Marcus har mycket roligt hänt. Achtung Bananen! 
Timmy, jag minns dig först som en uppkäftig Ling-Nollan för länge sedan, efter det har jag många andra och bättre minnen, tack för att du visade att landsvägscykling kunde vara så roligt, det har blivit några rundor, i sol, regn, snö och rusk. Jag vet var vi står.

Pratar man cykel måste man givetvis också nämna, Veronica och Daniel, Janosch (förstås), Herr Dr Marcus Speda, Patrik N, Kalle Skårbratt. Hoppas att vi inte tagit sista tramptaget ihop ännu. Vi måste cykla Hannibal-turen och ta oss upp för "Ont i arslet kullen" snart igen.

Sofie $\mathbf{N}$, den trygga klippan i Misfolding-grupperna, som vet när man behöver en kram, det enda jag saknar från pendlingen är dig, och kanske också pratet om det där Tranåspeket som skulle välta allt.

Madan, thank you, boss, always been a pleasure talking to you, and try to lure you away from a Friday meeting and take a beer instead, and as I told you, it will pass, Namaste!

De Tre P:na, Peter N, Per H, Peter K, som SYNTeskemist har man försökt att omvända er, till den rätta läran utan gitarrer, spandex och pudlar, men det var en reaktion svår att optimera, det utbytet blev lågt, riktigt lågt. :)

Veronica, Patricia, Cissi A, Maria Lunkan, att få smita ner till era kontor och bara prata av sig lite, har varit kul och också ibland nödvändigt. Tack för alla samtal!

Det är inte säkert att livet var bättre förr men det var i alla fall tätare besök på Fredagspuben, tack för alla väl spenderade timmar där, Janosch, Jussi, Jenny, Lan, Patrik N, Karin, Daniel K, Patrik L, Madhan, Lysholm, Bobo Selegård, Roger, Macke Bäck.

Brandon Boys, för att ni vet vad jag vill ha utan att behöva beställa.

Mina före detta kollegor på BioChromix AB, Peter Å, Anna H, Fredrik A, Josefine J, utan er hade nog inte intresset för forskning vaknat.

Alla medlemmar i forskarskolan, Forum Scientium, som gjort möten, studiebesök, work-shops, konferenser oförglömliga, vem minns inte Söderköping, eller Köpenhamn med ett extra stort leende.

Stefan Klinström, som tillsammans med Charlotte och Anette har hållit reda på allt runt Forskarskolan, och hjälpt till att göra tiden minnesvärd. 
Ett varmt tack till Annica Theresia Blissing för att du introducerade Naturvetenskapliga Forskarskolan i Karlskoga för mig, det har varit fyra fantastiskt roliga, inspirerande och lärorika år, tack också till alla handledare, och elever som gjorde det så bra, nu är det du Alexander Sandberg som får ansvara för LiUs heder, du klarar det, det vet jag $:$;

Pettson hittar du inte Findus? Eller går hon för tyst i korridoren?

En annan som fick mig att börja tänka på ett kemiskt liv igen är Anna-Lena Göransson, tack för all inspiration du gav under det där basåret i Tranås.

Roger S, Johan D, Elke S, för hjälp och trevligt samarbete under analytisk kemilabbarna jag undervisat i.

Tack till kemiavdelningens alla seniorer, administratörer, post-docs, dokrorander, stipendiater, ex-jobbare, som både gjort det kul och gör det kul att gå till jobbet.

Tack också till alla studenter som gjort min tid på LiU ljusare.

Gunnar B, Sara H, Erik M, för diskussioner om SPR och så mycket annat. $\mathbf{S}$ o $\mathbf{E}$ är fortfarande lite besviken att ni inte döpte Vidar till Plasmon.

PET-centrum i Uppsala, med Patrik och Gunnar A i spetsen.

$\mathrm{C}_{203} \mathbf{H}_{311} \mathbf{N}_{55} \mathbf{O}_{60} \mathbf{S}$ (på organiska), eller

DAEFRHDSGYEVHHQKLVFFAEDVGSNKGAIIGLMVGGVVIA (på biokemiska), eller "peptiden från helvetet" (på småländsköstgötska), du har ju varit med och gjort det här möjligt, så tack för all glädje och sorg just du bidragit med.

Moonspell, Daemonarch och The Cure, för uppiggande toner när skrivkrampen var som värst.

Min guy, Martin på LiUtryck, jag skrev och du tryckte, blev ju rätt bra till slut.

Ölmässegänget, Henrik, Erik, Micke H, Micke W, Danne, den där årliga traditionen med "kusinbarnen" är alltid lika efterlängtad, är lika spänd varje gång på hur många som verkligen kommer med tåget hem.

Jörgen W och Elenor med familj, det är så skönt att ha er, vi vet vad vi har varandra, och det finns ju alltid nått ämne att diskutera eller någon electrolåt att träta om. Jag säger bara; Rush! Eller kanske "jag är inte mig själv idag, jag är fast i en annan kropp”. 
Ammy, Tommy och Sara, för att jag fick öva mig på att undervisa för några år sedan, det fick mig att inse att det kanske är ditåt livet ska.

Mamma och pappa, ni har nog inte alltid förstått vad jag har hållit på med, men ni har förstått att stötta mig de här åren, Och det har räckt alldeles utmärkt, tack för att ni finns.

Janne W, bror med familj, Christina, Oscar, Lucas, Adam, Syster Tina med sin familj, Jonas, Kajsa, Lucas, Olliver, Elise Ni bor ju inte långt borta ändå är det så svårt att hinna träffas, men vi får väl ta tag $i$ det där nu.

Sist av allt vill jag påminna mig själv, inför framtiden, att jag faktiskt klarade av detta. Bra jobbat!!

Tack Leffe, det där gjorde du bra! 


\section{REFERENCES}

[1] J. Swanston, Thiophene, Wiley-VCH Verlag GmbH \& Co. KGaA, Weinheim, Germany, 2006. doi:10.1002/14356007.a26_793.pub2.

[2] A.D. Wilkinson, A. McNaught, Wilkinson: IUPAC Compendium of Chemical Terminology,... - Google Scholar, 1997.

[3] A.D. Jenkins, P. Kratochvil, R.F.T. Stepto, U.W. Suter, Glossary of basic terms in polymer science (IUPAC Recommendations 1996), Pure and Applied Chemistry. 68 (1996) 2287-2311. doi:10.1351/pac199668122287.

[4] S. Günes, H. Neugebauer, N.S. Sariciftci, Conjugated polymer-based organic solar cells, Chem. Rev. (2007).

[5] Y.-J. Cheng, S.-H. Yang, C.-S. Hsu, Synthesis of Conjugated Polymers for Organic Solar Cell Applications, Chem. Rev. 109 (2009) 5868-5923. doi:10.1021/cr900182s.

[6] A. Kraft, A.C. Grimsdale, A.B. Holmes, Electroluminescent conjugated polymersĐseeing polymers in a new light, Angew Chem Int End Engl. (1998).

[7] M.S. Alsalhi, J. Alam, L.A. Dass, M. Raja, Recent advances in conjugated polymers for light emitting devices, Int J Mol Sci. 12 (2011) 2036-2054. doi:10.3390/ijms12032036.

[8] D. Wang, X. Gong, P.S. Heeger, F. Rininsland, G.C. Bazan, A.J. Heeger, Biosensors from conjugated polyelectrolyte complexes, Proc Natl Acad Sci U S A. 99 (2002) 4953. doi:10.1073/pnas.012581399.

[9] S.J. Dwight, B.S. Gaylord, J.W. Hong, G.C. Bazan, Perturbation of fluorescence by nonspecific interactions between anionic poly(phenylenevinylene)s and proteins: implications for biosensors, J. Am. Chem. Soc. 126 (2004) 16850-16859. doi:10.1021/ja0469737.

[10] Q. Zhou, T.M. Swager, Method for enhancing the sensitivity of fluorescent chemosensors: energy migration in conjugated polymers, J. Am. Chem. Soc. 117 (1995) 7017-7018. doi:10.1021/ja00131a031.

[11] T. Yamamoto, K. Sanechika, A. Yamamoto, Preparation of thermostable and electric conducting poly(2,5-thienylene), Journal of Polymer Science: Polymer Letters Edition. 18 (1980) 9-12. doi:10.1002/pol.1980.130180103.

[12] J.W.P. Lin, L.P. Dudek, Synthesis and properties of poly(2,5-thienylene), Journal of Polymer Science: Polymer Chemistry Edition. 18 (1980) 2869-2873. doi:10.1002/pol.1980.170180910.

[13] K. Tamao, K. Sumitani, Y. Kiso, M. Zembayashi, A. Fujioka, S.-I. Kodama, et al., Nickel-Phosphine Complex-Catalyzed Grignard Coupling. I. Cross-Coupling of Alkyl, Aryl, and Alkenyl Grignard Reagents with Aryl and Alkenyl Halides: General Scope and Limitations, Bulletin of the Chemical Society of Japan. 49 (1976) 1958-1969. doi:10.1246/bcsj.49.1958.

[14] K. Yoshino, S. Hayashi, R.-I. Sugimoto, Preparation and Properties of Conducting Heterocyclic Polymer Films by Chemical Method, Jpn. J. Appl. Phys. 23 (1984) L899. doi:10.1143/JJAP.23.L899.

[15] R D McCullough, The Chemistry of Conducting Polythiophenes, Advanced Materials. 10 (1998) 93-116. doi:10.1002/(SICI)1521-4095(199801)10:2<93::AID-

ADMA93>3.0.CO;2-F.

[16] R D McCullough, R.D. Lowe, Enhanced electrical conductivity in regioselectively synthesized poly(3-alkylthiophenes), Journal of the Chemical Society, Chemical Communications. 0 (1992) 70-72. doi:10.1039/C39920000070.

[17] R S Loewe, S M Khersonsky, R D McCullough, A Simple Method to Prepare Head to-Tail Coupled, Regioregular Poly(3-alkylthiophenes) Using Grignard Metathesis, 
Advanced Materials. 11 (1999) 250-253. doi:10.1002/(SICI)15214095(199903)11:3<250::AID-ADMA250>3.0.CO;2-J.

[18] R.S. Loewe, P.C. Ewbank, J. Liu, L Zhai, R D McCullough, Regioregular, Head-to-Tail Coupled Poly(3-alkylthiophenes) Made Easy by the GRIM Method: Investigation of the Reaction and the Origin of Regioselectivity, .... (2001). doi:10.1021/ma001677.

[19] M. Andersson, P.O. Ekeblad, T. Hjertberg, O. Wennerström, O. Inganäs, Polythiophene with a free amino acid side chain, Polymer Communications. 32 (1991) 546-548.

[20] L. Ding, M. Jonforsen, L.S. Roman, M.R. Andersson, O. Inganäs, Photovoltaic cells with a conjugated polyelectrolyte, Synthetic Metals. 110 (2000) 133-140. doi:10.1016/S0379-6779(99)00284-2.

[21] M-G Baek, A. R C Stevens, D H Charych, Design and Synthesis of Novel Glycopolythiophene Assemblies for Colorimetric Detection of Influenza Virus and E. coli, Bioconjug. Chem. 11 (2000) 777-788. doi:10.1021/bc000026f.

[22] K.P.R. Nilsson, O. Inganäs, Chip and solution detection of DNA hybridization using a luminescent zwitterionic polythiophene derivative, Nature Materials. 2 (2003) 419_ 424.

[23] H.A. Ho, M. Boissinot, M.G. Bergeron, G. Corbeil, K. Doré, D. Boudreau, et al., Colorimetric and Fluorometric Detection of Nucleic Acids Using Cationic Polythiophene Derivatives, Angewandte Chemie. 114 (2002) 1618-1621. doi:10.1002/1521-3757(20020503)114:9<1618::AID-ANGE1618>3.0.CO;2-2.

[24] A. Åslund, A. Herland, P. Hammarström, K.P.R. Nilsson, B.-H. Jonsson, O Inganäs, et al., Studies of Luminescent Conjugated Polythiophene Derivatives: Enhanced Spectral Discrimination of Protein Conformational States, Bioconjugate .... 18 (2007) 1860-1868. doi:10.1021/bc700180g.

[25] M. Chayer, A. K Faïd, M Leclerc, Highly Conducting Water-Soluble Polythiophene Derivatives, Chem. Mater. 9 (1997) 2902-2905. doi:10.1021/cm970238v.

[26] D.H. Charych, J.O. Nagy, W. Spevak, M.D. Bednarski, Direct colorimetric detection of a receptor-ligand interaction by a polymerized bilayer assembly, Science. 261 (1993) $585-588$.

[27] K.P.R. Nilsson, J. Rydberg, L. Baltzer, O Inganäs, Self-assembly of synthetic peptides control conformation and optical properties of a zwitterionic polythiophene derivative, Proc Natl Acad Sci U S A. 100 (2003) 10170-10174. doi:10.1073/pnas.1834422100.

[28] J.D. Sipe, M.D. Benson, J.N. Buxbaum, S.-I. Ikeda, G. Merlini, M.J.M. Saraiva, et al., Nomenclature 2014: Amyloid fibril proteins and clinical classification of the amyloidosis, Amyloid. 21 (2014) 221-224. doi:10.3109/13506129.2014.964858.

[29] K. Maurer, S. Volk, H. Gerbaldo, Auguste D and Alzheimer's disease., 1997. doi:10.1016/S0140-6736(96)10203-8.

[30] A. Wimo, B. Winblad, Economical aspects of dementia, Handb Clin Neurol. 89 (2008) 137-146. doi:10.1016/S0072-9752(07)01213-4.

[31] T. Klingstedt, A. Åslund, R.A. Simon, L.B.G. Johansson, J.J. Mason, S. Nyström, et al., Synthesis of a library of oligothiophenes and their utilization as fluorescent ligands for spectral assignment of protein aggregates, Org. Biomol. Chem. 9 (2011) 83568370. doi:10.1039/c1ob05637a.

[32] D.J. Selkoe, Folding proteins in fatal ways, Nature. 426 (2003) 900-904. doi:10.1038/nature02264.

[33] C.M. Dobson, Protein folding and misfolding, Nature. 426 (2003) 884-890. doi:10.1038/nature02261.

[34] J.D. Harper, S.S. Wong, C M Lieber, J P T Lansbury, Assembly of A $\beta$ Amyloid Protofibrils: An in Vitro Model for a Possible Early Event in Alzheimer's Diseasef, 
[35] J.D. Harper, J P T Lansbury, Models of amyloid seeding in Alzheimer's disease and scrapie:Mechanistic Truths and Physiological Consequences of the Time-Dependent Solubility of Amyloid Proteins,

Http://Dx.Doi.org/10.1146/Annurev.Biochem.66.1.385. 66 (2003) 385-407. doi:10.1146/annurev.biochem.66.1.385.

[36] J.T. Jarrett, P.T. Lansbury Jr., Seeding “one-dimensional crystallization" of amyloid: A pathogenic mechanism in Alzheimer's disease and scrapie? Cell. 73 (1993) 1055-1058. doi:10.1016/0092-8674(93)90635-4.

[37] J.T. Jarrett, P.T. Lansbury, Amyloid fibril formation requires a chemically discriminating nucleation event: studies of an amyloidogenic sequence from the bacterial protein OsmB, Biochemistry. 31 (1992) 12345-12352.

doi:10.1021/bi00164a008.

[38] W.E. Klunk, J.W. Pettegrew, D.J. Abraham, Quantitative evaluation of congo red binding to amyloid-like proteins with a beta-pleated sheet conformation, J Histochem Cytochem. 37 (1989) 1273-1281. doi:10.1177/37.8.2666510.

[39] W.E. Klunk, M.L. Debnath, A.M. Koros, J.W. Pettegrew, Chrysamine-G, a lipophilic analogue of Congo red, inhibits A beta-induced toxicity in PC12 cells, Life Sci. 63 (1998) 1807-1814.

[40] P. Frid, S.V. Anisimov, N. Popovic, Congo red and protein aggregation in neurodegenerative diseases, Brain Res Rev. 53 (2007) 135-160. doi:10.1016/j.brainresrev.2006.08.001.

[41] M. Groenning, Binding mode of Thioflavin T and other molecular probes in the context of amyloid fibrils—current status, J Chem Biol. 3 (2010) 1-18. doi:10.1007/s12154-009-0027-5.

[42] D.B. Carter, K.C. Chou, A Model for Structure-Dependent Binding of Congo Red to Alzheimer $\beta$-Amyloid Fibrils, Neurobiol. Aging. 19 (1998) 37-40. doi:10.1016/S01974580(97)00164-4.

[43] F. Cavillon, A. Elhaddaoui, A.J.P. Alix, S. Turrell, M. Dauchez, Identification of the importance of the secondary structure of Alzheimer's disease amyloid, Journal of Molecular Structure. 408-409 (1997) 185-189. doi:10.1016/S0022-2860(96)09673-1.

[44] H. Inouye, J.T. Nguyen, P.E. Fraser, L.M. Shinchuk, A.B. Packard, D.A. Kirschner, Histidine residues underlie Congo red binding to A $\beta$ analogs, Amyloid. 7 (2009) 179188. doi:10.3109/13506120009146832.

[45] W.E. Klunk, M.L. Debnath, J.W. Pettegrew, Chrysamine-G binding to Alzheimer and control brain: autopsy study of a new amyloid probe, Neurobiol. Aging. 16 (1995) 541-548.

[46] W E Klunk, J Bacskai, C A Mathis, S T Kajdasz, M E McLellan, M P Frosch, et al., Imaging $A \beta$ Plaques in Living Transgenic Mice with Multiphoton Microscopy and Methoxy-X04, a Systemically Administered Congo Red Derivative, Journal of Neuropathology \& Experimental Neurology. 61 (2002) 797.

[47] H. Naiki, K. Higuchi, M. Hosokawa, T. Takeda, Fluorometric determination of amyloid fibrils in vitro using the fluorescent dye, thioflavine T, Anal Biochem. 177 (1989) 244-249. doi:10.1016/0003-2697(89)90046-8.

[48] 3. H LeVine, Thioflavine T interaction with synthetic Alzheimer's disease betaamyloid peptides: detection of amyloid aggregation in solution, Protein Science : a Publication of the Protein Society. 2 (1993) 404-410. doi:10.1002/pro.5560020312.

[49] C A Mathis, J Bacskai, S T Kajdasz, M E McLellan, M P Frosch, B T Hyman, et al., A lipophilic thioflavin-T derivative for positron emission tomography (PET) imaging of amyloid in brain, Bioorganic \& Medicinal Chemistry Letters. 12 (2002) 295-298. doi:10.1016/S0960-894X(01)00734-X. 
[50] C.A. Mathis, Y. Wang, D.P. Holt, G-F. Huang, M L Debnath, W E Klunk, Synthesis and Evaluation of 11C-Labeled 6-Substituted 2-Arylbenzothiazoles as Amyloid Imaging Agents, J. Med. Chem. 46 (2003) 2740-2754. doi:10.1021/jm030026b.

[51] W E Klunk, H. Engler, A. Nordberg, Y Wang, G. Blomqvist, D P Holt, et al., Imaging brain amyloid in Alzheimer's disease with Pittsburgh Compound-B, Ann. Neurol. 55 (2004) 306-319. doi:10.1002/ana.20009.

[52] A.K. Schütz, A. Soragni, S. Hornemann, A. Aguzzi, M. Ernst, A. Böckmann, et al., The amyloid-Congo red interface at atomic resolution, Angewandte Chemie International Edition. 50 (2011) 5956-5960. doi:10.1002/anie.201008276.

[53] U.S. Herrmann, A.K. Schütz, H. Shirani, D. Huang, D. Saban, M. Nuvolone, et al., Structure-based drug design identifies polythiophenes as antiprion compounds, Sci Transl Med. 7 (2015) 299ra123-299ra123. doi:10.1126/scitranslmed.aab1923.

[54] A. Åslund, C.J. Sigurdson, T. Klingstedt, S. Grathwohl, T. Bolmont, D.L. Dickstein, et al., Novel pentameric thiophene derivatives for in vitro and in vivo optical imaging of a plethora of protein aggregates in cerebral amyloidoses, ACS Chem Biol. 4 (2009) 673-684. doi:10.1021/cb900112v.

[55] K.P.R. Nilsson, A. Herland, Per Hammarström, O Inganäs, Conjugated Polyelectrolytes: Conformation-Sensitive Optical Probes for Detection of Amyloid Fibril Formationt, Biochemistry. 44 (2005) 3718-3724. doi:10.1021/bi047402u.

[56] A. Herland, K.P.R. Nilsson, J.D.M. Olsson, P. Hammarström, P Konradsson, O Inganäs, Synthesis of a Regioregular Zwitterionic Conjugated Oligoelectrolyte, Usable as an Optical Probe for Detection of Amyloid Fibril Formation at Acidic pH, J. Am. Chem. Soc. 127 (2005) 2317-2323. doi:10.1021/ja045835e.

[57] L.B.G. Johansson, R. Simon, G. Bergström, M. Eriksson, S. Prokop, C.-F. Mandenius, et al., An azide functionalized oligothiophene ligand - A versatile tool for multimodal detection of disease associated protein aggregates, Biosens Bioelectron. 63 (2015) 204 211. doi:10.1016/j.bios.2014.07.042.

[58] C.H. Heathcock, The aldol reaction: Acid and general base catalysis, Comprehensive organic synthesis, 1991.

[59] O. Diels, K. Alder, Synthesen in der hydroaromatischen Reihe, Justus Liebigs Annalen Der Chemie. 460 (1928) 98-122. doi:10.1002/jlac.19284600106.

[60] R.F. Heck, J.P. Nolley, Palladium-catalyzed vinylic hydrogen substitution reactions with aryl, benzyl, and styryl halides, J. Org. Chem. 37 (1972) 2320-2322. doi:10.1021/jo00979a024.

[61] T. Mizoroki, K. Mori, A. Ozaki, Arylation of Olefin with Aryl Iodide Catalyzed by Palladium, Bulletin of the Chemical Society of Japan. 44 (1971) 581-581. doi:10.1246/bcsj.44.581.

[62] G. Wittig, U. Schöllkopf, Über Triphenyl-phosphin-methylene als olefinbildende Reagenzien (I. Mitteil, Chemische Berichte. 87 (1954) 1318-1330. doi:10.1002/cber.19540870919.

[63] D.A. Shirley, The Synthesis of Ketones from Acid Halides and Organometallic Compounds of Magnesium, Zinc, and Cadmium, John Wiley \& Sons, Inc, Hoboken, NJ, USA, 1954. doi:10.1002/0471264180.or008.02.

[64] N. Miyaura, K. Yamada, A. Suzuki, A new stereospecific cross-coupling by the palladium-catalyzed reaction of 1-alkenylboranes with 1-alkenyl or 1-alkynyl halides, Tetrahedron Letters. 20 (1979) 3437-3440. doi:10.1016/S0040-4039(01)95429-2.

[65] N. Miyaura, A. Suzuki, Palladium-catalyzed cross-coupling reactions of organoboron compounds, Chem. Rev. (1995).

[66] J.K. Stille, The Palladium-Catalyzed Cross-Coupling Reactions of Organotin Reagents with Organic Electrophiles [New Synthetic Methods (58)], Angewandte Chemie International Edition. 25 (1986) 508-524. doi:10.1002/anie.198605081. 
[67] P.E. Fanta, The Ullmann synthesis of biaryls, Synthesis, 1974.

[68] J. Hassan, M. Sevignon, C. Gozzi, E. Schulz, Aryl-aryl bond formation one century after the discovery of the Ullmann reaction, Chemical .... (2002).

[69] Y. Sasson, Formation of Carbon-Halogen Bonds (Cl, Br, I), John Wiley \& Sons, Ltd, Chichester, UK, 2004. doi:10.1002/047002349X.ch11.

[70] E R Atkinson, M D Murphy, DL-4, 4', 6, 6'-tetrachlorodiphenicacid (DL-diphenic acid, 4, 4“, 6, 6-"tetrachloro-), ORGANIC ..., 1951.

[71] N. Miyaura, A. Suzuki, Stereoselective synthesis of arylated ( E )-alkenes by the reaction of alk-1-enylboranes with aryl halides in the presence of palladium catalyst, Journal of the Chemical Society, Chemical Communications. 0 (1979) 866-867. doi:10.1039/C39790000866.

[72] Huichang Zhang, Fuk Yee Kwong, A. Yuan Tian, K.S. Chan, Base and Cation Effects on the Suzuki Cross-Coupling of Bulky Arylboronic Acid with Halopyridines:

Synthesis of Pyridylphenols, J. Org. Chem. 63 (1998) 6886-6890. doi:10.1021/jo980646y.

[73] E A B Kantchev, C J O'Brien, M G Organ, Palladium complexes of N-heterocyclic carbenes as catalysts for cross-coupling reactions--a synthetic chemist's perspective, Angew. Chem. Int. Ed. Engl. 46 (2007) 2768-2813. doi:10.1002/anie.200601663.

[74] S Würtz, F Glorius, Surveying sterically demanding N-heterocyclic carbene ligands with restricted flexibility for palladium-catalyzed cross-coupling reactions, Acc. Chem. Res. 41 (2008) 1523-1533. doi:10.1021/ar8000876.

[75] C J O'Brien, E A B Kantchev, C Valente, N Hadei, G A Chass, A Lough, et al., Easily Prepared Air- and Moisture-Stable Pd-NHC (NHC=N-Heterocyclic Carbene) Complexes: A Reliable, User-Friendly, Highly Active Palladium Precatalyst for the Suzuki-Miyaura Reaction, Chemistry - a European Journal. 12 (2006) 4743-4748. doi:10.1002/chem.200600251.

[76] R. Gedye, F. Smith, K. Westaway, H. Ali, L. Baldisera, L. Laberge, et al., The use of microwave ovens for rapid organic synthesis, Tetrahedron Letters. 27 (1986) 279-282. doi:10.1016/S0040-4039(00)83996-9.

[77] M N Hopkinson, C. C Richter, M Schedler, F Glorius, An overview of N-heterocyclic carbenes, Nature. 510 (2014) 485-496. doi:10.1038/nature13384.

[78] H.C. Kolb, M.G. Finn, K.B. Sharpless, Click Chemistry: Diverse Chemical Function from a Few Good Reactions, Angewandte Chemie International Edition. 40 (2001) 2004-2021. doi:10.1002/1521-3773(20010601)40:11<2004::AID-

ANIE2004>3.0.CO;2-5.

[79] F. Himo, T. Lovell, R. Hilgraf, V.V. Rostovtsev, L. Noodleman, KB Sharpless, et al., Copper(I)-Catalyzed Synthesis of Azoles. DFT Study Predicts Unprecedented Reactivity and Intermediates, Journal of the .... 127 (2004) 210-216. doi:10.1021/ja0471525.

[80] L. Gaetke, Copper toxicity, oxidative stress, and antioxidant nutrients, Toxicology. 189 (2003) 147-163. doi:10.1016/S0300-483X(03)00159-8.

[81] Nicholas J Agard, A. Jennifer A Prescher, C R Bertozzi, A Strain-Promoted [3 + 2] Azide-Alkyne Cycloaddition for Covalent Modification of Biomolecules in Living Systems, American Chemical Society, 2004. doi:10.1021/ja044996f.

[82] J M Baskin, J A Prescher, S T Laughlin, N J Agard, P V Chang, I A Miller, et al., Copper-free click chemistry for dynamic in vivo imaging, Proc Natl Acad Sci U S A. 104 (2007) 16793-16797. doi:10.1073/pnas.0707090104.

[83] X. Ning, J. Guo, M A Wolfert, G.J. Boons, Visualizing Metabolically Labeled Glycoconjugates of Living Cells by Copper-Free and Fast Huisgen Cycloadditions, Angewandte Chemie International Edition. 47 (2008) 2253-2255. doi:10.1002/anie.200705456. 
[84] M F Debets, S S van Berkel, S Schoffelen, F P J T Rutjes, J C M van Hest, F L van Delft, Aza-dibenzocyclooctynes for fast and efficient enzyme PEGylation via copperfree (3+2) cycloaddition, Chem. Commun. (Camb.). 46 (2010) 97-99. doi:10.1039/b917797c.

[85] A Kuzmin, A Poloukhtine, M A Wolfert, V V Popik, Surface Functionalization Using Catalyst-Free Azide-Alkyne Cycloaddition, Bioconjug. Chem. 21 (2010) 2076-2085. doi:10.1021/bc100306u.

[86] N J Agard, J M Baskin, J A Prescher, A Lo, C R Bertozzi, A comparative study of bioorthogonal reactions with azides, ACS Chem Biol. 1 (2006) 644-648.

[87] Principles of Fluorescence Spectroscopy, (2013).

[88] J. Homola, Surface plasmon resonance sensors for detection of chemical and biological species, Chem. Rev. (2008).

[89] B. Liedberg, K. Johansen, Affinity Biosensing Based on Surface Plasmon Resonance Detection, in: Affinity Biosensors, Humana Press, New Jersey, 1998: pp. 31-54. doi:10.1385/0-89603-539-5:31.

[90] M.A. Cooper, M.A. Cooper, Optical biosensors in drug discovery, Nature Reviews Drug Discovery. 1 (2002) 515-528. doi:10.1038/nrd838.

[91] S. Löfås, B. Johnsson, A novel hydrogel matrix on gold surfaces in surface plasmon resonance sensors for fast and efficient covalent immobilization of ligands, Journal of the Chemical Society, Chemical Communications. 0 (1990) 1526-1528. doi:10.1039/C39900001526.

[92] H.-J. Wester, Nuclear imaging probes: from bench to bedside, Clin Cancer Res. 13 (2007) 3470-3481. doi:10.1158/1078-0432.CCR-07-0264.

[93] H.R. Herschman, Molecular imaging: looking at problems, seeing solutions, Science. 302 (2003) 605-608. doi:10.1126/science.1090585.

[94] S.M. Ametamey, M. Honer, P.A. Schubiger, Molecular imaging with PET, Chem. Rev. (2008).

[95] V. Leinonen, J.O. Rinne, K.A. Virtanen, O. Eskola, J. Rummukainen, J. Huttunen, et al., Positron emission tomography with $[18 \mathrm{~F}]$ flutemetamol and $[11 \mathrm{C}] \mathrm{PiB}$ for in vivo detection of cerebral cortical amyloid in normal pressure hydrocephalus patients, Eur. J. Neurol. 20 (2013) 1043-1052. doi:10.1111/ene.12102.

[96] A.E. Johnson, F. Jeppsson, J. Sandell, D. Wensbo, J.A.M. Neelissen, A. Juréus, et al., AZD2184: a radioligand for sensitive detection of beta-amyloid deposits, J.

Neurochem. 108 (2009) 1177-1186. doi:10.1111/j.1471-4159.2008.05861.x.

[97] J.O. Rinne, D.F. Wong, D.A. Wolk, V. Leinonen, S.E. Arnold, C. Buckley, et al., $[18 F]$ Flutemetamol PET imaging and cortical biopsy histopathology for fibrillar amyloid $\beta$ detection in living subjects with normal pressure hydrocephalus: pooled analysis of four studies, Acta Neuropathol. 124 (2012) 833-845. doi:10.1007/s00401012-1051-z.

[98] C.M. Clark, J.A. Schneider, B.J. Bedell, T.G. Beach, W.B. Bilker, M.A. Mintun, et al., Use of florbetapir-PET for imaging beta-amyloid pathology, Jama. 305 (2011) 275283. doi:10.1001/jama.2010.2008.

[99] G. Antoni, M. Lubberink, S. Estrada, J. Axelsson, K. Carlson, L. Lindsjö, et al., In vivo visualization of amyloid deposits in the heart with 11C-PIB and PET, J. Nucl. Med. 54 (2013) 213-220. doi:10.2967/jnumed.111.102053.

[100] C.J. Sigurdson, K.P.R. Nilsson, S. Hornemann, G. Manco, M. Polymenidou, P. Schwarz, et al., Prion strain discrimination using luminescent conjugated polymers, Nature Methods. 4 (2007) 1023-1030. doi:10.1038/nmeth1131.

[101] K.P.R. Nilsson, A. Åslund, I. Berg, S. Nyström, P. Konradsson, A. Herland, et al., Imaging Distinct Conformational States of Amyloid- $\beta$ Fibrils in Alzheimer's Disease Using Novel Luminescent Probes, ACS Chemical .... 2 (2007) 553-560. 
doi:10.1021/cb700116u.

[102] F. Karimi, B. Långström, Palladium -mediated carboxylation of aryl halides (triflates) or benzyl halides using [ $13 \mathrm{C}] /[11 \mathrm{C}]$ carbon monoxide with tetrabutylammonium hydroxide or trimethylphenylammonium hydroxide, Journal of the Chemical Society, Perkin Transactions 1. 0 (2002) 2256-2259. doi:10.1039/B206420K.

[103] A. Turner, I. Karube, G.S. Wilson, Biosensors : Fundamentals and Applications, (1987).

[104] Chemical Sensors and Biosensors, (2012).

[105] M.M. Pierce, C.S. Raman, B.T. Nall, Isothermal titration calorimetry of proteinprotein interactions, Methods. 19 (1999) 213-221. doi:10.1006/meth.1999.0852.

[106] Biocalorimetry 2, (2004).

[107] C.M. Johnson, Differential scanning calorimetry as a tool for protein folding and stability, Archives of Biochemistry and Biophysics. 531 (2013) 100-109. doi:10.1016/j.abb.2012.09.008.

[108] S. Nyström, K.M. Psonka-Antonczyk, P.G. Ellingsen, L.B.G. Johansson, N. Reitan, S. Handrick, et al., Evidence for Age-Dependent in Vivo Conformational Rearrangement within A $\beta$ Amyloid Deposits, ACS Chem Biol. (2013). doi:10.1021/cb4000376. 


\section{Papers}

The articles associated with this thesis have been removed for copyright reasons. For more details about these see:

http://urn.kb.se/resolve?urn=urn:nbn:se:liu:diva-122278 